\title{
The underestimated dynamics and impacts of water-based recreational activities on freshwater ecosystems
}

\begin{tabular}{|c|c|}
\hline Journal: & Environmental Reviews \\
\hline Manuscript ID & er-2017-0024.R2 \\
\hline Manuscript Type: & Review \\
\hline Date Submitted by the Author: & 04-Jan-2018 \\
\hline Complete List of Authors: & $\begin{array}{l}\text { Venohr, Markus; Leibniz-Institute of Freshwater Ecology and Inland } \\
\text { Fisheries, Ecohydrology } \\
\text { Langhans, Simone; Leibniz-Institute of Freshwater Ecology and Inland } \\
\text { Fisheries, Ecosystem Research } \\
\text { Peters, Oliver; Leibniz-Institute of Freshwater Ecology and Inland Fisheries, } \\
\text { Ecohydrology } \\
\text { Holker, Franz; Leibniz-Institute of Freshwater Ecology and Inland Fisheries, } \\
\text { Ecohydrology } \\
\text { Arlinghaus, Robert; Leibniz-Institute of Freshwater Ecology and Inland } \\
\text { Fisheries, Biology and Ecology of Fishes; Humboldt-Universität zu Berlin, } \\
\text { Division of Integrative Fisheries Management, Faculty of Life Sciences } \\
\text { Mitchell, Lewis; University of Adelaide, School of Mathematical Sciences } \\
\text { Wolter, Christian; Leibniz-Institute of Freshwater Ecology and Inland } \\
\text { Fisheries, Biology and Ecology of Fishes }\end{array}$ \\
\hline Keyword: & $\begin{array}{l}\text { recreation ecology, socio-environmental carrying capacity, integrative } \\
\text { management, usage peaks, social media }\end{array}$ \\
\hline
\end{tabular}

\section{SCHOLARONE ${ }^{m}$ \\ Manuscripts}


$112^{2}$ Department of Zoology, University of Otago, 340 Great King Street, Dunedin 9016, New

12 Zealand

$13{ }^{3}$ Division of Integrative Fisheries Management, Faculty of Life Sciences, Humboldt-University

14 Berlin, Germany

$15{ }^{4}$ School of Mathematical Sciences, University of Adelaide, Adelaide 5005, SA Australia

17 Address correspondence to Markus Venohr, Department Ecohydrology, Leibniz-Institute of

18 Freshwater Ecology and Inland Fisheries, Justus-von-Liebig-Str. 7, 12489 Berlin, Germany,

19 Telephone: +49-30-6392-4074, m.venohr@igb-berlin.de

20

21 Word count (including abstract, without acknowledgements and references): 8435 


\section{Abstract}

2 Recreational activities on, in and along freshwaters (e.g., boating, bathing, angling) positively

3 contribute to human well-being, but can concurrently stress aquatic ecosystems. While outdoor

4 recreation, aquatic ecosystems and human well-being form coupled social-ecological systems,

5 inherent fluxes and interactions between these have rarely been properly quantified. This paper

6 synthesizes information on links between water-based recreational activities, effects on

7 freshwater ecosystems integrity and recreational quality and proposes a novel framework for

8 assessment and integrated management. This framework is based on understanding relationships

9 between recreational quality, demand and use and recreational use-induced impacts on ecosystem

10 state and function as well as ecological and social carrying capacities. Current management

11 approaches of freshwater ecosystems addressing economic, environmental or recreational aspects

12 are poorly linked and harmonized, and are further constrained by inadequate information on the

13 dynamics and densities of recreational uses. Novel assessment and monitoring methods are

14 needed to capture the short-term peak dynamics of water-based recreational uses, and we argue

15 social media could play an increasingly important role here. An integrative recreation ecology

16 management concept combined with peak usage information, has great potential to form the basis

17 for next generation management approaches of freshwater and other ecosystems.

19 Keywords: recreation ecology, freshwater, social-environmental carrying capacity, social media, 20 usage peaks, integrative management. 


\section{Résumé (needs to be updated)}

2 Les activités récréatives sur, dans et à proximité des eaux douces (navigation, baignade, pêche...)

3 contribuent au bien-être humain, mais impactent ces écosystèmes. Activités récréatives,

4 écosystèmes aquatiques et bien-être humain forment un système d'interactions socio-écologiques,

5 bien que les flux inhérents et les interactions n'aient que rarement été quantifiés. Dynamique et

6 densité des usages guident la satisfaction perçue et les impacts environnementaux. Leur gestion

7 durable est limitée par manque d'informations sur leurs dynamiques spatio-temporelles (d'usage

8 et d'impacts écologiques). Cet article propose une synthèse exhaustive de la littérature sur les

9 liens entre activités récréatives, effets environnementaux, qualité des écosystèmes et satisfaction

10 de l'usager; et conceptualise les interactions socio-écologiques au sein d'un nouveau cadre de

11 gestion et d'évaluation de ces activités. Les données géoréférencées extraites des réseaux sociaux

12 (ici Twitter) y sont proposées pour approcher plus en détail dynamiques, timing et intensités des

13 usages aquatiques récréatifs. Ces données, calibrées sur les enregistrements d'activités, pourraient

14 constituer les outils de suivi 'next-gen' nécessaires pour l'évaluation des dynamiques et impacts

15 des usages récréatifs.

16 Mots-clés : écologie récréative, eaux douces, capacité d'accueil socio-environnementale, réseaux

17 sociaux, pics d'utilisation, gestion intégrée. 
1

\section{Introduction}

2 People heavily depend on surface waters. Surface waters provide a multitude of ecosystem

3 services (ESS) that contribute directly and indirectly, knowingly and unconsciously, to human

4 well-being through recreation, scenic value, biodiversity provision, and the provision of

5 nutritional products (e.g., Arlinghaus 2004; Bruce et al. 2005; Pretty et al. 2007).

6 Most people prefer to settle in the vicinity of freshwaters. Globally, approximately $50 \%$ of the

7 population lives within less than $3 \mathrm{~km}$ from freshwater ecosystems (Kummu et al. 2011). In urban

8 environments, promenades are commonly favorite places to spend time, and the mere existence

9 of surface waters potentially enhances human health and well-being (Völker and Kistemann

$102011,2013)$. Water is of such importance to people that visibility of surface water, compared to

11 other landscape features, accelerates property prices (Luttik 2000).

12 Water-based recreation is important to people but their spatio-temporal distributions are not well

13 known. However, official tourism data mostly neglect day-trips and only few scientific studies

14 explicitly consider them (Wynen 2013). Nonetheless, day-trips predominantly contribute to all 15 recreational activities, e.g. approximately $87 \%$ in Finland (Vesterinen et al. 2010) and 60-70\%

16 in the Netherlands, Germany, and Latvia (Eurostat 2013). Estimates on participation rates in

17 given recreational activities are mainly available from broad national or regional surveys, without

18 necessarily being scaled down to local demands and use intensities on specific freshwater

19 ecosystems (e.g., Arlinghaus et al. 2015). In contrast, locally monitored visitor numbers at

20 individual locations are typically rare and often have such specific aims and boundary conditions,

21 so that they cannot be easily scaled up to representative assessments of spatio-temporal use

22 intensities and analyses of the cultural value of ecosystems at regional or national scales (e.g.,

23 Cord et al. 2015). This pervasive knowledge gap on the spatio-temporal dynamics of recreational 
1 uses of aquatic ecosystems is a major limitation for economic, social, cultural and ecological

2 assessments of freshwaters (Sonter et al. 2016).

3 Environmental quality and recreational activities are closely linked. The attractiveness of a

4 location and its biodiversity can be strong factors attracting visitors (Habibullah et al. 2016), but

5 often cause conflicts between recreational interests and objectives of environmental protection,

6 for example when tourism hot spots overlap with threatened species (Siikamäki et al. 2015). A

7 range of negative impacts of recreational activities on species and ecosystem functioning have

8 been reported for terrestrial, marine, and coastal systems (Ballantyne et al. 2014, Roche et al.

9 2015, Barnett et al. 2016), as well as for lakes and rivers (Lewin et al. 2006, Marion et al. 2016),

10 but these strongly vary in space and time depending on both social and ecological contexts.

11 Cumulatively across freshwater-based recreation activities, it is unclear if and how much

12 recreational activities contribute to the global phenomenon that freshwater ecosystems are

13 subjected to far greater biodiversity loss than terrestrial and marine ecosystems (Bruce et al.

14 2005, Loh et al. 2005, Collen et al. 2014, Vidal-Abarca 2014).

15 In Europe, impacts from water based recreational activities, such as recreational angling, boating

16 or swimming, are perceived as pronounced; they rank fourth of all reported threats on freshwater

17 ecosystems (EEA 2015). Consequently, European countries evaluated the implementation of

18 protected areas as one of the five most beneficial measures to mitigate pressures from recreation

19 (EEA 2015). At the same time and surprisingly, according to the ecological status assessment

20 only 642 out of more than 127,000 European water bodies were classified as heavily modified

21 due to recreation as primary use (Fehér et al. 2012). In contrast, 58,400 (56\%) river water bodies

22 were found to significantly suffer from habitat loss and habitat alterations (Fehér et al. 2012).

23 This indicates a potentially systematic underestimation of impacts from water based recreational 
1 activities, and leads to the question whether classical conservationist approaches like protected

2 areas will succeed in achieving ecological improvements. Indeed, recreational impacts can be

3 managed using many other tools that do not prohibit access to a site entirely, such as spatial and

4 temporal zoning (Abell et al. 2007, Manning 2010). However, such management strategies

5 demand explicit local and regional knowledge about ecosystem status and recreational use, latter

6 acting as both, ecosystem service and stressor to the respective ecosystems. Such knowledge is

7 mostly missing, and overarching environmental policies, such as the European Union's Water

8 Framework Directive (2000/60/EC, WFD), are explicitly and solely ecosystem-status oriented,

9 neglecting the feedback of ecosystems to human well-being through recreation. The transfer from

10 ecological status to human well-being is conceptulised via ecosystem services, which yet rarely

11 consider trade offs between impacted water quality and water based recreational activities.

12 Accordingly, in Europe river basin management approaches currently focus primarily on

13 measures improving hydromorphology of and reducing nutrient inputs into surface waters rather

14 than on recreational uses (Fehér et al. 2012). Yet, it is completely unknown whether these

15 management approaches are sufficient to achieve the environmental targets, and whether

16 recreational uses interfere or compromise rehabilitation efforts.

17 Despite the current global deterioration of most ecosystems, including freshwaters (Dudgeon et 18 al. 2006), human well-being associated with the supply of cultural services from nature is 19 increasing (Raudsepp-Hearne et al. 2010, Shepherd et al. 2016). Limiting or prohibiting 20 recreational uses in protected areas is often heavily conflict-prone, because peoples' freedom of

21 choice is affected (Stoll-Kleemann 2010). Conflicting interests will possibly gain importance if,

22 as predicted by Gossling and Peeters (2015), the global impact and resources consumed by

23 tourism will increase by $92 \%$ for water during the period $2010-2050$. Though, it is widely

24 unkown whether the measures implemented to improve ecosystem status will also improve 
1 benefits to people. Future management of freshwaters should jointly protect ecosystem needs,

2 while considering people's recreational demands to secure the supply of the full range of ESS, as

3 well as those that are recreation-based (EEA 2015).

4 Human well-being and recreational quality has been found to increase with improving 5 environmental quality, e.g., bathing quality with increased water clarity (Graefe et al. 1984,

6 Bruce et al. 2005, Doi et al. 2013, Weyland and Laterra 2014). However, subjective, non7 monetary requirements to surface waters' quality could be uncoupled from environmental 8 conditions representing good ecological status (e.g., Collier 2014, Allan et al. 2015). For 9 example, increased water clarity in lakes and rivers is preferred by most swimmers, but could at 10 the same time reduce catch rates and therewith satisfaction of anglers (Arlinghaus et al. 2014).

11 This indicates that the link between ecological status and recreation quality is often not linear and 12 positive, and strongly varies subjectively and with recreation type.

13 This non-linearity between recreational preferences, ecological status and ecosystems'

14 degradation due to recreational uses potentially causes fundamental management trade-offs, but 15 is rarely assessed and considered when managing freshwater ecosystems. Assessing the multiple 16 and partly interacting pressures from recreational activities on aquatic ecosystems requires 17 profound knowledge on the ratio between ESS supply (Maes et al. 2013) and demand (Wolff et 18 al. 2015), as well as on their spatio-temporal dynamics. Only a small number of studies have 19 jointly evaluated supply and demand in aquatic environments (Burkhard et al. 2012, Villamagna 20 et al. 2014, Geijzendorffer and Roche 2014, Roche et al. 2015), while focusing on individual 21 recreation types (see e.g. Melstrom et al. 2015, Hunt et al. 2016 in recreational fishing). In 22 selected regions, first steps towards a change from single-objective, single-species management 23 to an ecosystem-based management approach, explicitly integrating socio-economic dimensions 
1 and human well-being, could be observed (FAO 2012). There exist first landscape models

2 developed for recreational fisheries that explicitly incorporate the multi-dimensional utility

3 offered by selected lakes or river sections and consider dynamic demand responding to local

4 changes in fishing quality (e.g., Hunt et al. 2011).

5 Most importantly, the few management approaches that do comprise interactions of multiple

6 recreational uses and their impacts on water quality, ecosystem status and ESS are rarely and

7 insufficiently considered by managers (Keeler et al. 2012, Russi et al. 2012, Hering et al. 2015).

8 Besides lacking proper monitoring data, one contributor to this negligence is the common

9 separation of responsibilities of public agencies in different sectors (e.g., water quality in

10 environmental ministries, fisheries in agricultural ministries, and tourism in development and

11 economics ministries).

12 This raises concerns as to whether different water-based recreational activities can be managed

13 jointly and sustainably while also targeting ecological status and ecosystem improvement (Monz

14 et al. 2013). Integration towards joint management frameworks in the field of recreation ecology

15 demands intensive attention to the bi-directional links between environmental and recreation

16 quality paired with socio-economic aspects of recreational preferences and perceived quality,

17 which is not the case at present. In short, an integrative management approach and assessments

18 with feedbacks among ecosystems, users, and management are needed. 


\section{Objectives}

2 We synthesize existing information on water-based recreational activities to conceptualize their

3 importance, dynamics, and potential impacts on ecosystem quality and management. First, we

4 evaluate current knowledge on the links between various recreational uses, quality of freshwaters,

5 and human perceptions and preferences in three areas: (1) the impacts of recreational activities on

6 aquatic ecosystems and water quality, (2) the link between perceived ecological site qualities and

7 participation in recreation, and (3) the needs for an improved consideration of the spatial

8 distribution and temporal dynamics of recreational activities. Our final goal is developing an

9 integral management and assessment framework to overcome current limitations in

10 understanding the importance of recreational activities for sustainable management of freshwater

11 ecosystems. To derive the required high spatio-temporal resolution of dynamics, timing, and

12 densities of water-based recreational uses, we include an outlook on how geotagged data from

13 social media platforms can be analyzed to help assess recreational activities. 


\section{Pressures and impacts of water-based recreational activities on aquatic ecosystems}

2 Outdoor recreation activities and tourism, even if well managed, can affect multiple ecosystem

3 functions and threaten biodiversity. We distinguished and elaborate on pressures and resulting

4 impacts on aquatic ecosystems in Table 1 . These are each linked to recreation type specific

5 impacts. It is becoming obvious that recreational activities can impact freshwater systems across

6 multiple levels of organization - from individuals to ecosystems. However, although the

7 knowledge of the ecological impacts of water-based recreational activities is still developing,

8 especially the ecosystem-scale ramifications have yet to be examined in detail.

9 Physical-chemical pressures resulting from recreational activities can impact aquatic ecosystems

10 in various ways, e.g. directly by noise or waves produced by boats or damage resulting from

11 trampling, or indirectly by increased concentrations of chemicals and organic substances (e.g.

12 nutrients, oil, toxic matrials, bacteria) or other materials (e.g. sediments, plastic, cigarette butts).

13 Damage of riparian vegetation along sea and lake shores by recreational visitors and its various

14 resulting consequences have been widely reported (Pickering and Hill 2007, Karwan et al. 2011,

15 Vlasov 2012, Monz et al. 2013, Ikomi and Arimoro 2014, Sweeney and Newbold 2014, Vidal-

16 Abarca 2014, Weirich and Miller 2014, Wyles et al. 2014, Rankin et al. 2015). An impairment of

17 riparian buffer strips can reduce their capacity to retain nutrients and fine sediment loads to

18 surface waters (Weissteiner et al. 2013) or to control shading / light availability and water

19 temperature (Sweeney and Newbold 2014). This can finally result in a habitat degradation or 20 loss.

21 Physical or chemical pressures caused by recreational activities include direct emissions of 22 nutrients from detergents, urea, ground baiting or feeding wild water birds, protozoans and 23 enteric viral pathogens, remains of sun-screens and cosmetics with UV-filters from water users, 
1 and direct emissions of engine oil spillage and anti-fouling paint residuals from recreational

2 boating, as well as effluents and run-off from accommodation roads and service facilities, boat

3 waves, light pollution along illuminated boat piers, biking and running paths, and noise generated

4 from visitors or engines (see Table 1).

5 Whereas some pressures are well analyzed and also quantified, others are rather under-studied in

6 the context of freshwater-based recreation activities. For example, at six Mediterranean beaches,

7 Munari et al. (2015) allocated 52\% of all remaining litter to shoreline and recreational activities

8 and about $40 \%$ to smoking. Nicotine loads from littered cigarette butts in waste water was further

9 identified as potential threat to urban waters (Roder Green et al. 2014). Nicotine and its

10 metabolites were found to alter heart rates and induce distortions in growth developments (e.g.,

11 eye distance or length) and anxiety-like behavioral responses in zebrafish and medaka embryos

12 (Lee and Lee 2015b, Stewart et al. 2015). Currently, no study is available on recreation-related

13 cigarette butt disposal, and the resulting nicotine concentrations and potential impacts on

14 freshwater ecosystems.

15 Similarly, scientific evidence is largely missing on residence time, aging, partitioning, and by16 products of UV-filters in freshwater systems, originating from sun-screens and cosmetics

17 entering surface water through swimmers or incomplete elimination in waste water treatment

18 plants. Studies explicitly addressing the impacts of sun-screens on freshwater organisms are

19 extremely rare (but see Díaz-Gil et al. 2017). In addition, evidence for microbiological

20 contamination of surface waters due to recreation is based on relatively few studies (Gerba 2000).

21 Hence, additional studies to assess the importance of microbial impacts on the bio-chemical

22 composition of water and habitat quality are required. 
1 Pressures from recreation activities can cause degradation or loss of habitats and, thus, potentially

2 impact diversity, composition, and abundance of freshwater organisms. Recreational activities

3 might also influence the physiology of animals and affect their behavior resulting in altered

4 species assemblages. For example, motorboat noise was found to directly modify fish assemblage

5 structure, as prey fishes were caught more easily by predators when exposed to noise (Simpson et

6 al. 2016). Recreational activity is further shaping aquatic biodiversity as an important vector for

7 invasive species, e.g. introduced by boats and gears used in different waters, through fish

8 stocking or illegally releasing of pets (Freyhof and Brooks 2011). 


\section{Link between perceived ecological site qualities and participation in recreation}

2 The engagement in recreational activities in, on or along freshwater ecosystems is a consequence

3 of users' preferences and the expected outcomes derived from recreational activities (Driver

4 1985, Hunt 2005, Manning 2010). Individual decisions on whether, where, when, and how to

5 spend recreation time is governed by a complex mixture of drivers. These include quality of

6 known sites, socialization into the activity, potential substitutes for preferred recreation activities,

7 tradition, weather forecasts, recent news articles, availability of time age, gender, education,

8 having children, or availability of a car (e.g., Hunt 2005, Brandenburg et al. 2007, Manning 2010,

$9 \quad$ Wynen 2013).

10 After a person has decided to participate in a recreational activity, the frequency of her

11 participation and her site choice is affected by multiple utility-determining criteria (Hunt 2005,

12 Hunt et al. 2007, Beardmore 2013, Dolnicar et al. 2015). Key criteria can be broken down into a

13 range of attributes (Freudenberg and Arlinghaus 2009) including: travelling and other costs,

14 environmental quality (determined for example by presence of iconic species, scenic appeal or

15 water clarity), social quality (e.g., crowding), infrastructure availability (e.g., boat ramps,

16 beaches, camp sites) and regulations (e.g., restrictions in the accessibility of recreation sites)

17 (Hunt 2005, Keeler et al. 2015a).

18 Research has shown that crowding, i.e. user densities, number of threatened and rare animals at a

19 site, water visibility, expected rewards such as spotting wild animals or catching fish in

20 recreational angling, run-off conditions, accessibility, available (or non-available) parking lots,

21 on-site staff etc. affect the exerted activities (Hunt 2005, Howat and Assaker 2013, Wood et al.

22 2013, Loomis and McTernan 2014, Keeler et al. 2015a). Some of these activities are directly or

23 indirectly affected by ecological attributes, e.g., scenic beauty, water clarity, quality of beaches 
1 and campsites in remote areas, and the availability of fish or wildlife. Thus, the experienced

2 recreational quality will be affected by the ecological status of a site or ecosystem, at least to

3 some degree. However, the importance of ecological attributes for how quality of a given locality

4 is perceived will strongly differ from person to person and from activity to activity. One example

5 is water clarity: whereas activities on and in freshwaters (e.g., swimming, boating, diving) are

6 usually fostered by clear water and little algae or macrophytes (Keeler et al. 2015a), some fishing

7 might be negatively affected, because clearer water usually means fewer fish (Baer et al., 2016).

8 Near-natural or wilderness areas are likely to positively affect wildlife-dependent recreational

9 uses (e.g., bird watching) that are often associated with preferences for near-natural shore

10 vegetation, macrophytes, and a diverse terrestrial and aquatic flora and fauna (Naidoo and

11 Adamowicz 2005, Johnstone and Markandya 2006, Arnegger et al. 2010, Conradie et al. 2013,

12 Kolstoe and Cameron 2017, Sorice et al. 2017). However, dense vegetation can also limit

13 accessibility of surface waters and will not universally be preferred by all user types (Eiswerth et

14 al. 2005). In fact, different recreational uses are not only associated with different demands on the

15 environmental settings but also with variation in demand for infrastructures (e.g., boat slips,

16 toilets, lights) (Hunt 2005).

17 In general, one can conclude that environmental quality is important to the utility derived by 18 users and there is ample variation in what exactly affects the demand of individuals. Moreover, 19 there might be ecological thresholds for the quality of some activities. However, recreational 20 requirements for water and quality traits of ecosystems as well as for site characteristics may, 21 depending on the respective use, deviate from environmental quality goals defined purely from 22 the perspective of environmental management or conservation. 
1 Given the above, a first step to link recreation ecology with conservation, using an explicit

2 feedback framework, needs properly defined preference functions of different user groups. First

3 studies that assessed stated or revealed user preferences reported alignments of surrogates of

4 ecosystem quality and user preferences. For example, users' perception of the quality of surface

5 waters was found to be in line with the observed water quality at a selected site (Smith et al.

6 2015). Also, users correlated the degradation of the recreational value of water-based activities in

7 urban waters in Vienna with the degrading status of the respective aquatic biodiversity

8 (Steinwender et al. 2008). However, functional links among user preferences and ecosystem

9 quality remain often vague and describe broad classes of quality indicators, e.g., water clarity

10 (Silva 2014). Moreover, visitors and recreational users such as swimmers or boaters often assess

11 water quality by visual and olfactory senses (Lee and Lee 2015a, Smith et al. 2015) and not

12 necessarily by considering overall ecological quality including a holistic assessment of multiple

13 ecological criteria.

14 Satisfied water quality expectations can result in maintaining visiting rates and lead to loyalty to a 15 specific location, i.e. the intention to revisit (Taplin 2013, Melstrom et al. 2015). Keeler et al. 16 (2015) found that improved water quality was associated with an increased number of visits to

17 lakes in northern USA, and visitors were willing to travel approximately one hour farther for 18 every meter of increased water clarity. Also, in Finland, increased water clarity of $1 \mathrm{~m}$ was 19 predicted to result in an $6 \%$ and $15 \%$ increase in swimmers and fishers, respectively, however no 20 effects were predicted for boating (Vesterinen et al. 2010). Whether increased water clarity 21 correlates with an improvement in other ecosystem traits (e.g., biodiversity), and how this is 22 perceived by visitors, is less clear. It is likely that trade-offs are involved that vary with the 23 respective recreational activity. For example, high water clarity will benefit scenic beauty and 
1 swimming, but decrease fish productivity and may render boating more difficult when intensive

2 macrophyte beds develop in shallow water (which in turn can impact swimmers).

3 Generally, when asked in abstract terms, people prefer "good" water quality in surveys, but

4 quality aspects may not always be relevant or not primarily relevant when choosing a destination.

5 This is particularly true in cases when holidays are planned several months in advance, as

6 revealed by a survey at the German Baltic coast (Dolch and Schernewski 2002, Preißler 2008).

7 Consequently, a distinction must be made between holidays and regional, day- or weekend-trips.

8 Regardless of their quality, water body types seem to be relevant for the selection process, as they

9 provide a different spectrum of opportunities for recreation activities. For example, lakes in

10 northern Germany were visited by more people but less frequently than rivers (BTU-Cottbus

11 2014). Further, even within a user group, for example recreational anglers, different water body

12 types will be preferred (Arlinghaus 2004, Hunt et al. 2011 Ward et al. 2013b). Water bodies in

13 vicinity to urban areas, with preeminent recreation qualities or infrastructures (e.g., boat ramps)

14 will attract disproportionally high levels of visitors, potentially predisposing these systems to

15 excessive impacts such as overfishing (Ward et al. 2013a, Mee et al. 2016). This in turn will

16 affect the future quality and demand of these systems (e.g., Hunt et al. 2011). Although water

17 quality or ecological traits in general (e.g., biodiversity) appear to be important criteria for

18 recreational visits to surface waters, as far as we are aware, no study describes lower water

19 quality thresholds as decisive for recreational participation, except when explicitly hazardous to

20 health (e.g., due to excess of E. coli thresholds).

21 Some water-based recreational activities do not depend on high environmental quality and can

22 utilize entirely artificial environments, for example biking or dog walking. Consequently, further

23 work is needed to link objective measures of ecological quality with demand for recreation, and 
1 understand how this varies with culture, region, and type of recreational activity. This work then

2 needs to be coupled within an explicit feedback loop to recreation-induced ecosystem impacts to 3 be able to study relationships among quality and demand and learn what the systematic effects of 4 management interventions are. 
1 Conceptual framework to link recreational satisfaction, recreational use and ecosystem

2 impact in freshwater ecosystems

3 Currently, academic and managerial silos prevent developing integrative assessments of and

4 management approaches for outdoor recreation in and around aquatic ecosystems. Within the

5 recreation-oriented social sciences, there is also little integration among social-psychological

6 approaches and recreation economics (Fenichel et al. 2013). Moreover, there is very little

7 integration of applied social/economic and ecological sciences and management components

8 dealing with conservation and ecosystem quality in freshwater systems, which motivated us to

9 develop a framework to link the disjointed concepts.

10 Of key importance in the proposed framework is to conceptualize the decision-making process of

11 users and how it is linked to ecosystem quality. According to economic theory, preferences by

12 users are expressed in choices they make to maximize the utility associated with recreation at a

13 given site (Hunt 2005). Thus, changes to attributes that determine utility affect participation

14 decisions (Hunt 2005). Social-psychologists in the field of outdoor recreation pursue a

15 comparable framing, but use different concepts and terminologies (Manning 2010). In that

16 particular research tradition, people are seen to participate in outdoor recreation to satisfy their

17 needs (Manfredo et al. 1996). There are many factors that determine both utility and satisfaction

18 (Hendee 1974, Driver 1985, Arlinghaus 2006, Arlinghaus et al. 2014) and the importance of each

19 factor varies among people, even when they engage in the same activity. This is reflected in

20 heterogeneous user preferences, expectations, and behavior (Johnston et al. 2010). Logically,

21 different recreation activities will tap into different attributes of the social-ecological environment

22 to a different degree. Expectations of utility to be enjoyed at a given site as well as structural

23 conditions within society (e.g., amount of free time, income, knowledge of how to participate in a 
1 given activity) and supply (availability and quality of sites), will in turn determine peoples'

2 participation decisions. These participation decisions will leave impacts in the ecosystem and

3 affect the social environment (e.g., crowding), thereby changing the local recreational qualities

4 (as a function of the ecological, social and structural environment), which in turn leads to new

5 individual-based participation decisions in space and time.

6 A simple conceptual model (Figure 1) describes the resulting links between ecosystem and 7 recreational quality (represented as recreation demand) and ultimately realized ecological 8 services (represented as recreation use). The term recreation demand here considers, beyond the 9 attractiveness of a site, factors like the size of the population living within travel distance, 10 accessibility and awareness of a site or concurring recreational sites as substitutes.

11 Recreational demand for each site is also expected to be a function of environmental quality 12 (Bockstael et al. 1987), as shown for boating, fishing, and swimming. This acknowledges that 13 environmental quality is just one of several dimensions that affect recreation demand. We 14 disentangle ecosystem status from perceived ecosystem quality to unveil an environmental 15 quality that ultimately drives choice behavior of users. For example, several studies explored how 16 changes in water quality affect recreational demand, and estimated the demand as a function of 17 different characteristics such as fish catch rates (Englin et al. 1997, Massey et al. 2006), Secchi 18 depth, dissolved oxygen level, temperature, chemical oxygen demand (COD), turbidity, $\mathrm{pH}$, and 19 color (Bockstael et al. 1987, Egan et al. 2004). Several functional forms such as linear (Bockstael 20 et al. 1989, Parsons and Jo Kealy 1994, Pendleton 1994, Whitehead et al. 2008, Keeler et al. 21 2015b), quadratic, and semi-log (Eom and Larson 2006) were used widely in the application of

22 the empirical demand models, suggesting that ecosystem quality plays a role, although is not 23 necessarily the prime driver of demand and does not necessarily link quality and demand linearly. 
1 For social-ecological systems sigmoidal relationships are commonly used to describe regime

2 shifts and to derive thresholds, when systems shift to a new stable state after a perturbation

3 (Schlüter et al. 2012), e.g. when peaks in recreational activities disrupt ecological processes (e.g.,

4 Biggs et al. 2009). There is some evidence from recreation choice models and satisfaction studies

5 suggesting that the probability of user participation as well as their satisfaction can scale non-

6 linearly with changes in utility-determining attributes, particularly in relation to ecosystem

7 quality (e.g. fish abundance and catch rates in recreational angling; Hunt et al. 2011, Arlinghaus

8 et al. 2014, Johnston et al. 2015). Because recreational demand is limited by the regional

9 population size and available leisure time, and as further ecosystem traits are only some of many

10 factors affecting utility, we thus propose a sigmoidal relationship to describe recreational demand

11 as a function of ecosystem quality (Figure 1a). The asymptote maybe caused by negative effects

12 on user satisfaction correlating with increased demand and user density, e.g., effects of crowding.

13 We exemplify this possibility by the grey horizontal area in Figure 1a. However, this function is

14 scale dependent and visitor growth can, at a single site in a landscape, also appear to be

15 unlimited. At the lower part of the curve in Figure 1a, the effect of poor ecosystem quality may

16 vary for different recreational use types. For example, while for bathing a minimum standard of

17 the water quality exists below which participation drops to zero (e.g., very turbid, algae rich

18 water or when water quality poses a health risk), recreational angling or boating might still be

19 performed, resulting in a positive intercept with the demand axis (Figure 1a).

20 We follow Monz et al. (2013), who also suggested a sigmoidal-shaped curve for the relationship

21 between recreational uses (the actual number of visitors) and ecosystem impact (Figure 1b). Few

22 visitors, below a primary ecological threshold, cause only little and reversible damage, whereas at

23 high use levels, when the ecological carrying capacity is exceeded (secondary threshold), any

24 further increases cause little additional ecological damage. The cause-response functions may 
1 again differ between different recreational activities and aquatic ecosystems, which is a matter of

2 thorough empirical study in the emerging field of recreation ecology (Monz et al. 2013).

3 Assuming that both ecological and social status (e.g., with respect to crowding) affect the quality

4 of a local recreational experience at a given site, leads to at least two potential conditions that will

5 limit recreational quality and, hence, recreational demand. Demand should be constrained if 1)

6 the environmental quality of freshwaters and/or riparian areas becomes unacceptably low, and/or

7 2) the local user density becomes too high causing social impacts, thereby reducing the 8 experienced recreational quality (e.g., Graefe et al. 1984; Navarro Jurado et al. 2012; Salerno et 9 al. 2013). Both conditions depend on the ecological and social resilience of the ecosystem, on 10 culture, the type of social community (e.g., urban or rural community), the kind of recreational 11 use (e.g., whether it is social or not), and the subjective perception of local conditions by 12 individual users. Different adaptation strategies to unacceptable environmental or social quality 13 will apply for individual users, e.g. visiting different water bodies at different times of day or 14 changing recreational activity). This may result in substitution of users with higher tolerances 15 (e.g., for crowding) or with different preference structures (Manning 2010). These substitution 16 patterns might initially create stability in local recreational use (and also in average user 17 satisfaction when measured on site, Manning 2010) unless the conditions deteriorate further and 18 effectively reduce recreational use.

19 In general, peoples' local and regional preferences at available sites and substitution relationships 20 among sites will determine complex patterns that define whether a change in either ecological or

21 social quality affects average recreational quality (and recreational satisfaction).

22 We propose to simplify a complex situation that varies strongly across regions and activities by 23 assuming that recreational demand is unlikely to grow infinitely with increasing recreational 
1 quality. Rather, recreational demand might reach some ceiling determined by the size of the

2 regional population of users in light of the supply of recreational opportunities (Figure 1c). In

3 fact, unless we deal with a tourism destination where travelers can be drawn almost without limit,

4 there will be leisure time limits in any given regional population from which a site or ecosystem

5 can "draw" only a limited number of people independent of the recreational quality of the site.

6 For example, factors such as urbanization or weekly working hours exert negative effects on

7 participation rates in recreational activities (Post et al. 2008, Arlinghaus et al. 2015). However,

8 increasing recreational quality exerts linearly and fosters participation (Fix and Loomis 1998,

9 Hunt et al. 2017). Thus, in Figure 1c we assume a region where increases in recreation quality

10 affect recreation demand linearly and positively, until reaching a ceiling caused by constrains on

11 leisure time by a finite population of recreationists.

12 In Figure 1a we conceptualize that saturation of demand with increasing ecosystem quality occurs

13 where social carrying capacity is exceeded. However, we acknowledge that this concept is

14 volatile and strongly affected by local and regional contexts and may vary substantially from

15 person to person (as shown by the grey area). We nevertheless use social carrying capacity

16 because of its conceptual similarity to ecological carrying capacity, which is popular in

17 conservation sciences. We believe that these descriptions can help us navigate the interaction of

18 recreation, quality, and impact (Figure 1). We note that both social and ecological carrying

19 capacity could be operationalized by context depending multiple measures. Social carrying

20 capacity involves crowding or other issues that correlate with number of people, e.g., littering,

21 constrained ability to enjoy freedom of choice (e.g., with taking services or fishing sites), or

22 regulatory constraints (e.g., temporal zoning) that reduce satisfaction. Shelby and Heberlein

23 (1986) used perceived crowding as an evaluative standard in defining social carrying capacity,

24 and this conceptualization is common in leisure sciences related to outdoor recreation (Manning 
1 2010). The concept of social carrying capacity is then described as unacceptably high visitor 2 densities, which has been applied for diving (Zhang and Chung 2015), boating (Lorenz and Pusch

3 2012, Lorenz et al. 2013), fishing (Hunt 2005, Arlinghaus et al. 2014) or island visitors (Viñals et

4 al. 2016). When quantifying the impacts of carrying capacities on satisfaction and demand, social

5 carrying capacity appeared as potentially, but not always, more limiting than environmental

6 carrying capacity (Santiago et al. 2008, Lorenz and Pusch 2012, Lorenz et al. 2013). However,

7 social carrying capacity extends the mere interaction of "too many people" to also affecting more

8 fundamental components of an outdoor experience, such as altering the feeling of self-

9 determination and losing control over personal choice (e.g., of sites) during recreation (Manning 10 2010).

11 Conceptualizing thresholds with the help of social and ecological carrying capacities is useful for 12 outlining key dynamic interactions among quality, demand, use, and impacts that can either have 13 an amplifying or a dampening effect (Figure 2). High ecosystem quality increases demand, which 14 positively affects recreational use. As long as the ecosystem impact of such level of recreation 15 remains low enough (e.g., water quality is still acceptable), and/or the visitor density is below a 16 certain threshold (e.g., social carrying capacity for crowding is not exceeded for most visitors,

17 Figure 1a), recreation satisfaction by those that choose to visit a site remains high. Management 18 interventions can then further improve environmental (or social quality, e.g., through 19 infrastructure, Fig. 3), further fostering demand and use. At higher recreation use, however, 20 ecological and/or social carrying capacities might be exceeded (Figure 2). This can lead to either 21 declining ecosystem status, reducing demand, or reducing the social quality of the experience, 22 again reducing demand and in turn use. Both amplifying and de-amplifying recreational loops 23 can occur depending on the social-ecological context and dynamics. An alternative scenario is 24 simply self-regulation, when reduced demand helps ecosystem and social qualities to recover. 
1 Local and regional specificities (e.g., supply and demand and alternative uses of ecosystems for

2 non-recreation activities) will determine the interplay of the factors shown in Figure 2 and its

3 trajectories.

4 Finally, we add the management perspective and link the recreational and ecological quality

5 loops with management and policy decision making (Figure 3). Importantly, from a recreation

6 ecology perspective we propose the management loop should not only evaluate the ecosystem

7 status, but also recreational quality and base decisions on an integrated assessment of ecology and

8 social dimensions. Such management is currently rarely done as most aquatic ecosystem

9 management is predominantly focused on ecological targets. The management loop we suggest

10 balances recreational use and carrying capacities (ecological and social), while considering often

11 competing freshwater and catchment uses (e.g., agriculture, energy production). The ecological

12 quality loop addresses the links between extent and combination of stressors, ecosystem

13 resilience, and impacts on aquatic ecosystems and habitats (Figure 3Figure ). However,

14 depending on institutions and countries, management commonly focuses either on the

15 recreational site or on the ecological site (like the WFD) or Nature Conservation Legislation).

16 These isolated views are expected to produce only suboptimal outcomes (Johnston et al. 2010,

17 Levin et al. 2013). Therefore, we propose a framework that facilitates the integrated assessment

18 of recreational and ecological health of aquatic ecosystems. In this sense, the management loop

19 can be understood as a connecting element to achieve balanced functioning and provisioning of

20 ecological quality and recreational quality, respectively, in light of stakeholder objectives.

21 Recreational uses and their management have to be assessed and implemented in addition to

22 ecological rehabilitation measures for example to improve water and habitat quality (Hall et al.

23 2014), minimize health risks (e.g., from harmful algal blooms and pollution), and sustain and if

24 possible improve recreational qualities for a variety of user groups. Although the present model is 
1 meant to show the interactions and feedbacks and is focused on aquatic ecosystems, it

2 conceptually considers stressors originating from "external" social-ecological systems like waste

3 water discharges or agriculture. 
1 Improved assessment of the spatial distribution and temporal dynamics of recreational

\section{2 activities}

3 In order to put the frameworks elaborated in Figures 2 to 4 into operationalization, there is an

4 urgent need to improve visitor monitoring and assessment methods accounting for the spatio-

5 temporal dynamics of recreational activities in a landscape of lakes and rivers. Such assessments

6 help understand demand and monitor use and analyze and predict recreational impacts as well as

7 responses of users to changes in the environment. Ecologically, different recreational activities

8 predispose disproportional pressure levels and combinations on aquatic ecosystems. However,

9 current practices to determine cultural, recreation-based ESS are usually not sufficient to link

10 recreational uses, impacts, and ecosystem functioning. A clear identification of links between

11 recreational activities and ecosystem conditions and, vice versa, between ecological site quality

12 and recreational quality and user satisfaction has to enumerate and consider distinct recreational

13 users in combination with spatio-temporal patterns of water body uses.

14 Annual averages of highly skewed distributions, e.g., average numbers of boats passing a river

15 section or swimmers in a lake are not suitable to quantify their potential impacts on aquatic

16 habitats, flora, and fauna and on water quality during usage peaks (Arlinghaus and Mehner 2003,

17 Wolter et al. 2003, Arlinghaus 2004). These aggregated data are also inadequate to develop

18 predictive models of user dynamics and to infer user preferences from observed behaviors.

19 Because day and weekend trips constitute the biggest share of all recreational activities (e.g.,

20 Vesterinen et al. 2010), they are expected to peak at few weekends during the high season. Thus,

21 ecological impacts of recreational activities should be better assessed as short-term, extreme

22 events like peak uses rather than according to annual averages. For example, daily visitor counts

23 from 2013 to 2015 provided by the Berliner Bäder-Betriebe (BBB, the company that maintains 
1 the public swimming pools and beaches in Berlin) show a strong increase of daily visitors with

2 increasing maximum daily air temperatures. Natural bathing waters received $30 \%$ of all visitors

3 during the $5 \%$ hottest days. Visitor numbers were significantly higher during weekends and

4 holidays compared to working days (Figure 4Error! Reference source not found.). In contrast,

5 days with maximum air temperatures below $30{ }^{\circ} \mathrm{C}$ or less than six hours of sunshine resulted in

6 significantly lower visitor numbers. This is just one example of highly skewed distributions of

7 recreational users that demand sophisticated, high intensity sampling programs and alternative

8 real-time assessments methods additionally to on-site visits. We advocate for a greater use of

9 social media data as one of the toolboxes that could be used for monitoring recreational activities

10 in the future.

11 It could also be important to consider visitor monitoring and assessment methods accounting for

12 daily dynamics of recreational activities (Cooke et al. 2017). For example, recreational fishing at

13 night is quite popular due to its environmental (presence of nocturnal species, scenic appeal) and

14 social quality (less crowded). In addition, several recreational uses (e.g. boating, biking, running)

15 require the installation of artificial lights along boat piers, and biking and running paths that are

16 potentially impacting aquatic systems at night (Perkin et al. 2011). Because the night is an

17 ecologically relevant time period for many aquatic organisms - $30 \%$ of all vertebrates and over

$1860 \%$ of invertebrates are nocturnal (Hölker et al. 2010) - aggregated daily data are inadequate for

19 developing management concepts to mitigate potential ecological impacts of nocturnal

20 recreational activities.

21 Currently, recreational uses of freshwaters are locally determined by visitor counts or more often

22 inferred from surveys asking for visiting frequency "after the fact" (i.e., offsite surveys by mail or

23 phone). Visitor counts provide true numbers, but they can hardly be generalized for other 
1 locations and are often costly and difficult to generate for large spatial scales, as for example

2 hundreds of lakes in a water-rich landscape. Recreational activities determined from surveys are

3 in turn often spatially inexplicit and cannot be used to assess waterbody-specific uses. Also, as

4 noted before, recreational activities derived from statistics mostly provide averages or only

5 consider rough frequencies or distributions of visits, but not the temporal dynamics or timing of

6 visits (Vesterinen et al. 2010, BTU-Cottbus 2014).

7 There are some models that describe daily visitors and recreational uses as a function of external

8 variables, but these are either not directly related to rivers and lakes (Cole et al. 2005, Resource

9 Systems Group 2013), or they only address site-specific activities (e.g., Santiago et al. 2008).

10 Individuality and spatio-temporal heterogeneity in users and spatial ecological conditions

11 considerably complicate the modelling of social-ecological systems, but their consideration is of

12 utmost importance for sustaining ESS (Levin et al. 2013). Activity-specific counts, densities,

13 spatio-temporal distributions, and frequencies of recreational uses as well as the spatio-temporal

14 configuration of different user types may be much stronger predictors to assess ecological

15 impacts of recreational uses. This is in agreement with Bujosa et al. (2015) who found user

16 densities, rather than absolute counts, are a much better descriptor to assess user preferences

17 when analyzing onsite recreational activities. Quantifying user density, however, requires

18 detailed knowledge on the number of users, the size of a specific location, and on the timing of

19 recreational uses. At larger scales, heterogeneity in recreational uses cannot be determined with

20 any available approach or data set yet. Especially challenging is the quantification of the various

21 individual, license-free recreational activities such as swimming, bathing, kayaking, and boating.

22 Analysis of social media could provide one alternative to traditional on-site user count and off-

23 site survey methods. 
1 In conclusion, a sufficient temporal resolution of recreational activity peaks and dynamics on and

2 along freshwaters is missing for most ecosystems. Instead, what is usually available is simply 3 national level interest or participation data in certain recreational uses or local-level assessment

4 data for selected recreational activities. What is needed, though, is regional-level assessment of 5 all recreational activities at temporal and spatial scales that are conducive to water-body specific 6 management. 
1 Using social media data for identifying spatial and temporal use patterns of water-based

\section{2 recreation}

3 Social media, such as Facebook, Flickr, Twitter, and Instagram among others, are increasingly

4 used in private and professional contexts worldwide. With enabled GPS devices, activities on

5 social media platforms, i.e. posting messages on Twitter or uploading pictures on Flickr, are

6 tagged with the coordinates of the user's location, which generates geotagged data. Geotagged

7 data can be accessed in real-time, and the visiting times and locations can be further linked to on-

8 site characteristics including weather conditions, sunshine duration, and accessibility of the site.

9 This enables spatio-temporal explicit analyses of peoples' recreational activities (Sonter et al.

10 2016) including environmental triggers and potential effects on ecosystems. Such data offer an

11 unprecedented opportunity of monitoring and assessing recreational activities at site-specific and

12 larger spatial scales. Geotagged data are increasingly used to explore business-related, political,

13 or social topics (e.g., Piryani et al. 2017). However, they have rarely been used in ecological

14 contexts.

15 In a freshwater recreation context, one of the first attempts to obtain travelling distance

16 information used geotagged Flickr data and combined these with water quality parameters and

17 cost estimates in a classical travel cost model (Wood et al. 2013, Keeler et al. 2015a). Howarth

18 (2014) used photos from Flickr and Google Panoramio to model the spatial distribution of

19 recreational activities at the Great Barrier Reef, which were found to concentrate around tourist

20 infrastructures and particular islands rather than along the reef itself. Daume (2016) analyzed the

21 content of 2842 tweets as reference for invasive alien species and concluded that tweets are a rich

22 source of biodiversity information. Mitchell et al. (2013) analyzed the sentiment and expression

23 of 80 million words derived from geotagged twitter messages and linked them to environmental 
1 conditions to create a map of happiness across the USA. Orsi and Geneletti (2013) used 2 geotagged Flickr and Panoramio photographs to feed a gravity model estimating the volume of 3 visitor flows from access points at an Italian UNESCO World Heritage Site. This method allowed 4 estimating visitor flows over a large trail network and assessing the intensity of trampling 5 damages. Sonter et al. (2016) used geotagged data from social media to study temporal dynamics 6 and values of nature based recreation activities within conserved lands in Vermont, USA. They 7 found that using social media can help to correct misleading results from static models on the 8 impact and importance of landscape attributes. Similar approaches describing spatio-temporal 9 visitor dynamics on and along lakes and rivers are still missing, and are suggested as future 10 impact assessment and management tool in the context of recreation ecology. Clearly, calibration 11 studies are needed to see if social media-derived patterns agree with validated on-site measures 12 either assessed by visual counts through interviewers or by use of cameras, flights, drones, or 13 vehicle counting devices. Once social media data are calibrated, however, they can serve as a 14 powerful tool to assess the spatio-temporal patterns of recreational uses. When combined with 15 further information on site and ecosystem characteristics, e.g., those assessed with real-time 16 sensors, remote sensing or through citizen science, such data could be used to analyze, describe 17 and predict use intensities. Personalized data from selected social media could then also be used 18 to study preferences using variants of choice modelling or with machine learning applications. 


\section{Conclusions}

2 Outdoor recreation and aquatic ecosystems can be considered as bi-directionally coupled social-

3 ecological systems, whose fluxes (services and benefits) and interactions have rarely been

4 properly quantified (Jobstvogt et al. 2014, Villamagna et al. 2014). Direct effects of recreational

5 uses on ecosystems and biodiversity have been described in several individual studies, but

6 feedbacks to a range of different recreational demand types (activities) and human well-being

7 have usually been neglected or not quantified at large scales (Arlinghaus et al. 2017). A joint and

8 harmonized management framework that considers recreational demands, environmental impacts

9 resulting from recreation, and ecological targets, is missing, and we envisage that the framework

10 we propose inspires further work.

11 Currently, water quality, navigation, recreation, and other water uses are commonly managed by

12 different agencies at different administrative levels with some recreation activities such as

13 individual bathing hardly managed at all. Different users are often in conflict where one activity

14 inflicts on the quality of another. Management is needed to develop solutions that maximize the

15 well-being of as many people as possible while minimizing ecological impacts and therefore

16 reaching ecological quality standards. Today, regulations and management of a range of

17 recreational activities around waters are poorly linked and harmonized. However, all these

18 outdoor activities and aquatic ecosystems form complex and interlinked social-ecological

19 systems, which have to be jointly considered to minimize ecosystem impacts and increase human

20 well-being and ecosystem service flows. Because recreational uses and their impacts on lakes and

21 rivers are not treated in an integrative manner across administrative sectors, current conservation

22 strategies are also insufficient to stop biodiversity loss and may at the same time even harm the

23 quality of the cultural services that ecosystems provide (Santos-Martín et al. 2013). This 
1 commonly results in support of only one single, politically most preferred water-based ESS,

2 without feedback from other intended and unintended developments. For example in Germany,

3 large rivers are utilized as waterways and hence are managed to improve the economic service of

4 navigation, which leads to substantial habitat and ecological impairments (Liedermann et al.

5 2014) while negatively affecting recreation. As another example, in Europe, objectives of the

6 EU-WFD entail reaching a good ecological status, which is not necessarily associated with the

7 interests of recreational activities and other ESS, e.g. nutritional limitations for fish production or

8 impeded accessibility of surface waters for bathers by dense riparian buffer strips or macrophytes

9 (Terrado et al. 2016). By contrast, the number of waters primarily managed for recreation is -

10 with the exception of angling - currently limited, although it is recreation by which the majority

11 of society personally interacts with natural aquatic ecosystems. The environmental triggers for

12 recreational quality and user satisfaction as well as potential feedback to the other management

13 cycles that are associated with water and ecosystems certainly need further investigation.

14 It is not intended to question the environmental goals of regulations like the EU-WFD, but given

15 the socio-economic importance of recreational activities a harmonization of the various

16 management goals seems inevitably needed. Balancing demands for recreational uses on, in, and

17 along waters with conservation and management of biodiversity and other ESS would

18 significantly improve existing management approaches. Possibly, an integrative view that

19 considers human well-being as a whole would come up with strikingly different management

20 scenarios than the ones that are currently focused on selected ecosystem status targets or human

21 uses of ecosystems (e.g., navigation).

22 In many areas of the world, recreational uses on and along freshwaters have not yet been spatio-

23 temporally explicitly estimated. However, this is vital to understand the links between various 
1 recreational uses and freshwater quality conditions as well as human preferences and to tailor

2 management approaches. The joint evaluation of ESS supply and demand is also a major 3 prerequisite and profound element of the emerging science of recreation ecology. A detailed 4 quantification of recreational uses not only links these to pressures on freshwater systems, but 5 allows estimating timing, frequency, and utilization peaks of recreational activities. These spatio6 temporal dynamics of recreational uses enable the analyses of processes, i.e. how extreme events, 7 peak pressures, frequency, and duration of recreational uses interfere with or impact on 8 ecosystem processes and functions, such as juvenile fish recruitment (e.g., Wolter and Arlinghaus 92003 ) or filter activity of unionid mussels (e.g., Lorenz et al. 2013) . Correlations between water 10 quality, weather conditions, and recreational uses could also allow estimating limiting factors and 11 main drivers for changing uses and defining appropriate indicators. We present the potential of 12 geotagged data, e.g. from Twitter, for analyzing recreational activities with high temporal 13 resolution at large spatial scales. This opens up novel opportunities to derive use dynamics, 14 frequencies, and dynamics of recreational activities as inputs for the integrated frameworks 15 presented in this paper. 


\section{Acknowledgements}

2 The authors acknowledge funding from the European Commission 7th Framework Program

3 through the project MARS (Managing Aquatic ecosystems and water resources under multiple

4 stress; www.mars-project.eu), the German Ministry of Education and Research through the

5 projects RESI (River Ecosystem Service Index; http://www.igb-berlin.de/projekt/resi) and

6 AQUATAG, and additional funding through the IGB funding program Frontiers. We further

7 thank the Berliner Bäder-Betriebe (BBB) for providing visitor numbers of natural bathing waters

8 and Dr. Roshni Arora for processing the data. We also acknowledge the E-OBS dataset from the

9 EU-FP6 project ENSEMBLES (http://ensembles-eu.metoffice.com) and the data providers in the

10 ECA\&D project (http://www.ecad.eu). We are grateful for the extremely helpful comments of

11 two anonymous reviewers and the editor to improve the manuscript. 


\section{References}

Abell, R., Allan, J.D., and Lehner, B. 2007. Unlocking the potential of protected areas for freshwaters. Biol. Conserv. 134(1): 48-63. doi:10.1016/j.biocon.2006.08.017.

Allan, J.D., Smith, S.D.P., Mcintyre, P.B., Joseph, C.A., Dickinson, C.E., Marino, A.L., Biel, R.G., Olson, J.C., Doran, P.J., Rutherford, E.S., Adkins, J.E., and Adeyemo, A.O. 2015. Using cultural ecosystem services to inform restoration priorities in the Laurentian Great Lakes. Front. Ecol. Environ. 13(8): 418-424. doi:10.1890/140328.

Arlinghaus, R. 2004. Angelfischerei in Deutschland - eine soziale und ökonomische Analyse. In Heft 18. Edited byLeibniz-Institut für Gewässerökologie und Binnenfischerei (IGB) im Forschungsverbund Berlin e.V. Berlin.

Arlinghaus, R. 2006. On the Apparently Striking Disconnect between Motivation and Satisfaction in Recreational Fishing: The Case of Catch Orientation of German Anglers. North Am. J. Fish. Manag. 26(3): 592-605. doi:10.1577/M04-220.1.

Arlinghaus, R., Alós, J., Beardmore, B., Daedlow, K., Dorow, M., Fujitani, M., Hühn, D., Haider, W., Hunt, L.M., Johnson, B.M., Johnston, F., Klefoth, T., Matsumura, S., Monk, C., Pagel, T., Post, J.R., Rapp, T., Riepe, C., Ward, H., and Wolter, C. 2017. Understanding and Managing Freshwater Recreational Fisheries as Complex Adaptive Social-Ecological Systems. Rev. Fish. Sci. Aquac. 25(1): 1-41.

Arlinghaus, R., Beardmore, B., Riepe, C., Meyerhoff, J., and Pagel, T. 2014. Species-specific preferences of German recreational anglers for freshwater fishing experiences, with emphasis on the intrinsic utilities of fish stocking and wild fishes. J. Fish Biol. 85(6): 18431867. doi:10.1111/jfb.12546. 
1 Arlinghaus, R., and Mehner, T. 2003. Socio-economic characterisation of specialised common

2 carp (Cyprinus carpio L.) anglers in Germany, and implications for inland fisheries management and eutrophication control. Fish. Res. 61(1-3): 19-33. doi:10.1016/S01657836(02)00243-6.

Arlinghaus, R., Tillner, R., and Bork, M. 2015. Explaining participation rates in recreational fishing across industrialised countries. Fish. Manag. Ecol. 22(1): 45-55. doi:10.1111/fme.12075.

Arnegger, J., Woltering, M., and Job, H. 2010. Toward a product-based typology for naturebased tourism: a conceptual framework. J. Sustain. Tour. 18(7): 915-928. Routledge. doi:10.1080/09669582.2010.485680.

Bacela-Spychalska, K., Grabowski, M., Rewicz, T., Konopacka, A., and Wattier, R. 2013. The "killer Shrimp" dikerogammarus villosus (crustacea, amphipoda) invading alpine lakes: Overland transport by recreational boats and scuba-diving gear as potential entry vectors? Aquat. Conserv. Mar. Freshw. Ecosyst. 23(4): 606-618. doi:10.1002/aqc.2329.

Baer, J., Eckmann, R., Rösch, R., and Arlinghaus, R. 2016. Managing Upper Lake Constance Fishery in a Multi- Sector Policy Landscape: Beneficiary and Victim of a Century of Anthropogenic Trophic Change. Inter-Sectoral Gov. Inl. Fish. (Photo 1): 1-15.

Ballantyne, M., Gudes, O., and Marina, C. 2014. Landscape and Urban Planning Recreational trails are an important cause of fragmentation in endangered urban forests: A case-study from Australia. Landsc. Urban Plan. 130: 112-124. Elsevier B.V. doi:10.1016/j.landurbplan.2014.07.004.

Barnett, A., Payne, N.L., Semmens, J.M., and Fitzpatrick, R. 2016. Ecotourism increases the field 
metabolic rate of whitetip reef sharks. BIOC 199: 132-136. Elsevier Ltd. doi:10.1016/j.biocon.2016.05.009.

Barros, A., and Marina Pickering, C. 2017. How Networks of Informal Trails Cause Landscape Level Damage to Vegetation. Environ. Manage. 60(1): 57-68. Springer US. doi:10.1007/s00267-017-0865-9.

Beachler, M.M., and Hill, D.F. 2003. Stirring up Trouble? Resuspension of Bottom Sediments by Recreational Watercraft. Lake Reserv. Manag. 19(1): 15-25. doi: $10.1080 / 07438140309353985$.

Beardmore, B. 2013. The Importance of Understanding Angler Heterogeneity for Managing Recreational Fisheries. Simon Fraser University.

Biggs, R., Carpenter, S.R., and Brock, W.A. 2009. Turning back from the brink: detecting an impending regime shift in time to avert it. Proc. Natl. Acad. Sci. U. S. A. 106(3): 826-31. doi:10.1073/pnas.0811729106.

Bockstael, N.E., McConnell, K.E., and Strand, I.E. 1989. Measuring the Benefits of Improvement in Water Quality: The Chesapeake Bay. Mar. Resour. Econ. 6(1): 1-18.

Bockstael, N.E., Strand, I.E., and Hanemann, W.M. 1987. Time and the Recreational Demand Model. Am. J. Agric. Econ. 69(2): 293. doi:10.2307/1242279.

Bonanno, S.E., Leopold, D.J., and Hilaire, L.R. St. 1998. Vegetation of a Freshwater Dune Barrier Under High and Low Recreational Uses. J. Torrey Bot. Soc. 125(1): 40-50. Available from http://www.jstor.org/stable/2997230.

Boyle, A., and Samson, F.B. 1985. Effects of Nonconsumptive Recreation on Wildlife : A 
Review. Wildl. Soc. Bull. 13(2): 110-116. Available from http://www.jstor.org/stable/3781422.

Brandenburg, C., Matzarakis, A., and Arnberger, A. 2007. Weather and cycling - a first approach to the effects of weather conditions on cycling. Meteorol. Appl. 14: 61-67. doi:10.1002/met.6.

Brauns, M., Wagner, C., Garcia, X., Walz, N., and Pusch, M.T. 2011. Human lakeshore development alters the structure and trophic basis of littoral food webs. : 916-925. doi:10.1111/j.1365-2664.2011.02007.x.

Bruce, A., Bandyopadhyay, J., Belausteguigotia, J., Bo, P., Cassar, A., Meadors, L., Saade, L., Siebentritt, M., Stein, R., Tortajada, C., Allan, T., Bauer, C., Bruch, C., Guimaraes-pereira, A., Kendall, M., Landry, C., Rodriguez, E.M., Meinzen-Dick, R., Moellendorf, S., Porras, I., Ratner, B., Shea, A., Swallow, B., Thomich, T., Voutchkov, N., Editors, R., Constanza, R., Jacobi, P., and Rijsberman, F. 2005. Freshwater Ecosystem Services. In Millennium Ecosystem Assessment. Island Press. Available from http://www.millenniumassessment.org/documents/document.312.aspx.pdf.

BTU-Cottbus. 2014. Stickstofflimitation in Binnengewässern: Ist Stickstoffreduktion ökologisch sinnvoll und wirtschaftlich vertretbar? Abschlussbericht des BMBF-Verbundprojekts NITROLIMIT I. BTU Cottbus-Senftenberg, Lehrstuhl Gewässerschutz (Hrsg.).

Bujosa, A., Riera, A., Hicks, R.L., and McConnell, K.E. 2015. Densities Rather than Shares: Improving the Measurement of Congestion in Recreation Demand Models. Environ. Resour. Econ. 61(2): 127-140. Springer Netherlands. doi:10.1007/s10640-014-9785-9.

Burger, J. 1998. Effects of Motorboats and Personal Watercraft on Flight Behavior over a Colony 
of Common Terns. Condor 100(3): 528-534.

2

3

4

Burgin, S. 2017. Indirect Consequences of Recreational Fishing in Freshwater Ecosystems : An Exploration from an Australian Perspective. doi:10.3390/su9020280.

Burkhard, B., Kroll, F., Nedkov, S., and Müller, F. 2012. Mapping ecosystem service supply, demand and budgets. Ecol. Indic. 21: 17-29. Elsevier Ltd. doi:10.1016/j.ecolind.2011.06.019.

Cambray, J.A. 2003. Impact on indigenous species biodiversity caused by the globalisation of alien recreational freshwater fisheries. Hydrobiologia 500: 217-230.

Carney, K.M., and Sydeman, W.J. 1999. A review of human disturbance effects on nesting colonial waterbirds. Waterbirds 22(1): 68-79. doi:10.2307/1521995.

Chapman, R., and Jones, D.N. 2009. Just feeding the ducks : quantifying a common wildlifehuman interaction Author. The Sunbird 39(2): 19-28.

Cole, D.N., Cable, S., Gimblett, R., Hallo, J.C., Newman, P., and Vallerie, W.A. 2005. Computer Simulation Modeling of Recreation Use: Current Status, Case Studies, and Future Directions. Fort Collins.

Collen, B., Whitton, F., Dyer, E.E., Baillie, J.E.M., Cumberlidge, N., Darwall, W.R.T., Pollock, C., Richman, N.I., Soulsby, A.M., and Böhm, M. 2014. Global patterns of freshwater species diversity, threat and endemism. Glob. Ecol. Biogeogr. 23(1): 40-51. doi:10.1111/geb.12096.

Collier, M. 2014. Novel ecosystems and the emergence of cultural ecosystem services. Ecosyst. Serv. 9: 166-169. doi:https://doi.org/10.1016/j.ecoser.2014.06.002. 
1 Conradie, N., Zyl, C. Van, and Strasheim, A. 2013. What inspires birders to migrate South 2 towards Africa? A quantitative measure of international avitourist motivation. South. $3 \quad$ African Bus. Rev. 17(1): 128-167.

4 Cooke, S.J., and Cowx, I.G. 2006. Contrasting recreational and commercial fishing: Searching

5 for common issues to promote unified conservation of fisheries resources and aquatic environments. Biol. Conserv. 128(1): 93-108. doi:10.1016/j.biocon.2005.09.019.

7 Cooke, S.J., Lennox, R.J., Bower, S.D., Treml, M.K., Stoddard, E., Donaldson, L.A., and Danylchuk, A.J. 2017. Fishing in the dark : the science and management of recreational $9 \quad$ fisheries at night. Bull. Mar. Sci. 93(2): 519-538.

10 Cord, A.F., Roeßiger, F., and Schwarz, N. 2015. Geocaching data as an indicator for recreational ecosystem services in urban areas: Exploring spatial gradients, preferences and motivations. Landsc. Urban Plan. 144: 151-162. Elsevier B.V. doi:10.1016/j.landurbplan.2015.08.015.

Darrigran, G. 2002. Potential impact of filter-feeding invaders on temperate inland freshwater environments. Biol. Invasions (Simberloff 2001): 145-156.

Daume, S. 2016. Ecological Informatics Mining Twitter to monitor invasive alien species - An analytical framework and sample information topologies. Ecol. Inform. 31: 70-82. Elsevier B.V. doi:10.1016/j.ecoinf.2015.11.014.

Díaz-Gil, C., Cotgrove, L., Smee, S.L., Simón-Otegui, D., Hinz, H., Grau, A., Palmer, M., and Catalán, I.A. 2017. Anthropogenic chemical cues can alter the swimming behaviour of juvenile stages of a temperate fish. Mar. Environ. Res. 125: 34-41. doi:10.1016/j.marenvres.2016.11.009.

22 Doi, H., Katano, I., Negishi, J.N., Sanada, S., and Kayaba, Y. 2013. Effects of biodiversity, 
habitat structure, and water quality on recreational use of rivers. Ecosphere 4(8): 1-11.

Dolch, T., and Schernewski, G. 2002. Hat Wasserqualität eine Bedeutung für Touristen? Eine Studie am Beispiel des Oderästuars. In Aktuelle Ergebnisse der Küstenforschung. 20. AMKTagung Kiel, 30.5- 1.6.2002. Berichte aus dem Forschung- undTechnologiezentrum Westküste der Universität Kiel. Edited by A. Dascheit and H. Sterr. Büsum. pp. 197-205.

Dolnicar, S., Coltman, T., and Sharma, R. 2015. Do Satisfied Tourists Really Intend to Come Back? Three Concerns with Empirical Studies of the Link between Satisfaction and Behavioral Intention. J. Travel Res. 54(2): 152-178. doi:10.1177/0047287513513167.

Driedger, A.G.J., Dürr, H.H., Mitchell, K., and Cappellen, P. Van. 2015. Plastic debris in the Laurentian Great Lakes : A review. J. Great Lakes Res. 41(1): 9-19. International Association for Great Lakes Research. doi:10.1016/j.jglr.2014.12.020.

Driver, B.L. 1985. Specifying what is produced by management of wildlife by public agencies. Leis. Sci. 7(3): 281-295. doi:http://dx.doi.org/10.1080/01490408509512126.

Dudgeon, D., Arthington, A.H., Gessner, M.O., Kawabata, Z.-I., Knowler, D.J., Lévêque, C., Naiman, R.J., Prieur-Richard, A.-H., Soto, D., Stiassny, M.L.J., and Sullivan, C.A. 2006. Freshwater biodiversity: importance, threats, status and conservation challenges. Biol. Rev. Camb. Philos. Soc. 81(2): 163-82. doi:10.1017/S1464793105006950.

Eagleston, H., and Marion, J.L. 2017. Sustainable campsite management in protected areasA study of long-term ecological changes on campsites in the boundary waters canoe area wilderness, Minnesota, USA. J. Nat. Conserv. 37: 73-82. Elsevier GmbH. doi:10.1016/j.jnc.2017.03.004.

EEA. 2015. State of nature in the EU - Results from reporting under the nature directves 2007- 
Egan, K.J., Herriges, J.A., Kling, C.L., Downing, J.A., Egan, K.J., Herriges, J.A., Kling, C.L., and Downing, J.A. 2004. Recreation Demand Using Physical Measures of Water Quality of Water Quality. CARD Work. Pap. Paper 394. Available from http://lib.dr.iastate.edu/card_workingpapers/394\%0AThis.

Eiswerth, M., Darden, T., Johnson, W., Agapoff, J., and Harris, T. 2005. Input-output modeling, outdoor recreation, and the economic impacts of weeds. Weed Sci. 53(1): 130-137. doi:doi:10.1614/WS-04-022R.

Englin, J., Lambert, D., and Shaw, W.D. 1997. A Structural Equations Approach to Modeling Consumptive Recreation Demand. J. Environ. Econ. Manage. 33(1): 33-43. doi:10.1006/jeem.1996.0976.

Eom, Y.S., and Larson, D.M. 2006. Improving environmental valuation estimates through consistent use of revealed and stated preference information. J. Environ. Econ. Manage. 52(1): 501-516. doi:10.1016/j.jeem.2005.11.001.

Eurostat. 2013. Tourism satellite accounts (TSA) in Europe. Luxembourg: Publications Office of the European Union. doi:http://bookshop.europa.eu.

FAO. 2012. Technical guidelines for responsible fisheries - Recreational Fisheries. In Fisheries Management. Rome.

Fehér, J., Gáspár, J., Veres, K.S., Kiss, A., Globevnik, L., Peterlin, M., Kirn, T., Stein, U., Prins, T., Spiteri, C., Laukkonen, E., Heiskanen, A.-S., Austner, K., Semeradova, S., and Künitzer, A. 2012. Hydromorpholgical alterations and pressures in European rivers, lakes, transitional and coastal waters. European topic centre for assessment by EEA water report, Prague. 
1 Fenichel, E.P., Abbott, J.K., and Huang, B. 2013. Modelling angler behaviour as a part of the management system: Synthesizing a multi-disciplinary literature. Fish Fish. 14(2): 137-157. doi:10.1111/j.1467-2979.2012.00456.x.

Fix, O., and Loomis, J. 1998. Comparing the economic value of mountain bikingusing revealed and stated preferences. J. Environ. Plan. Manag. 41(2): 227-236.

Freudenberg, P., and Arlinghaus, R. 2009. Benefits and Constraints of Outdoor Recreation for People with Physical Disabilities: Inferences from Recreational Fishing. Leis. Sci. 32(1): 55-71. doi:10.1080/01490400903430889.

Freyhof, J., and Brooks, E. 2011. European red list of freshwater fishes. Luxembourg: Publications Office of the European Union. doi:doi:10.2779/85903.

Gabel, F., Garcia, X.F., Schnauder, I., and Pusch, M.T. 2012. Effects of ship-induced waves on littoral benthic invertebrates. Freshw. Biol. 57(12): 2425-2435. doi:10.1111/fwb.12011.

Gabel, F., Lorenz, S., and Stoll, S. 2017. Effects of ship-induced waves on aquatic ecosystems. Sci. Total Environ. 601-602: 926-939. Elsevier B.V. doi:10.1016/j.scitotenv.2017.05.206.

Gabel, F., Pusch, M.T., Breyer, P., Burmester, V., Walz, N., and Garcia, X.F. 2011. Differential effect of wave stress on the physiology and behaviour of native versus non-native benthic invertebrates. Biol. Invasions 13(8): 1843-1853. doi:10.1007/s10530-011-0003-1.

Geijzendorffer, I.R., and Roche, P.K. 2014. The relevant scales of ecosystem services demand. Ecosyst. Serv. 10: 49-51. Elsevier. doi:10.1016/j.ecoser.2014.09.002.

Gerba, C.P. 2000. Assessment of enteric pathogen shedding by bathers during recreational activity and its impact on water quality. Quant. Microbiol. 2(1): 55-68. 
doi:10.1023/A:1010000230103.

Gossling, S., and Peeters, P. 2015. Assessing tourism's global environmental impact 1900-2050. J. Sustain. Tour. 23(5): 639-659. Taylor \& Francis. doi:10.1080/09669582.2015.1008500.

Gozlan, R.E., Peeler, E.J., Longshaw, M., St-hilaire, S., and Feist, S.W. 2006. Effect of microbial pathogens on the diversity of aquatic populations, notably in Europe. Microbes Infect. 8 8: 1358-1364. doi:10.1016/j.micinf.2005.12.010.

Graefe, A.R., Vaske, J.J., and Kuss, F.R. 1984. Social carrying capacity: An integration and synthesis of twenty years of research. Leis. Sci. 6(4): 395-431. doi:10.1080/01490408409513046.

Graham, A.L., and Cooke, S. 2008. The effects of noise disturbance from various recreational boating activities common to inland waters on the cardiac physiology of a freshwater fish, the largemouth bass (Micropterus salmoides). Aquat. Conserv. Mar. Freshw. Ecosyst. 18: 1315-1324. doi:DOI: 10.1002/aqc.941.

Grubisic, M., Singer, G., Bruno, M.C., van Grunsven, R.H.A., Manfrin, A., Monaghan, M.T., and Hölker, F. 2017. Artificial light at night decreases biomass and alters community composition of benthic primary producers in a sub-alpine stream. Limnol. Oceanogr. 62(6): 2799-2810. doi:10.1002/lno.10607.

Habibullah, M.S., Din, B.H., Chong, C.W., and Radam, A. 2016. Tourism and Biodiversity Loss: Implications for Business Sustainability. Procedia Econ. Financ. 35(October 2015): 166172. Elsevier B.V. doi:10.1016/S2212-5671(16)00021-6.

Hall, H.R., McCarty, C., and Clark, M.W. 2014. Regulatory protection and definition for recreational uses of Florida lakes. Lake Reserv. Manag. 30(2): 115-118. 
doi:10.1080/10402381.2014.898349.

He, X., Hörmann, G., Strehmel, A., Guo, H., and Fohrer, N. 2015. Natural and Anthropogenic Causes of Vegetation Changes in Riparian Wetlands Along the Lower Reaches of the Yellow River, China. Wetlands 35(2): 391-399. doi:10.1007/s13157-015-0628-4.

Helmers, A., Platek, A., Ponte, M., Secen, N., and Cottenie, K. 2016. The impacts of anthropogenic disturbance on plant species richness in the freshwater lakes of Algonquin Provincial Park. Stud. by Undergrad. Res. Guelph Vol. 9(1): 5-13.

Hendee, J.C. 1974. A Multiple-Satisfaction Approach to Game Management. Wildl. Soc. Bull. 2(3): 104-113.

Hering, D., Carvalho, L., Argillier, C., Beklioglu, M., Borja, A., Cristina, A., Duel, H., Ferreira, T., Globevnik, L., Hanganu, J., Hellsten, S., Jeppesen, E., Kode, V., Lyche, A., Nõges, T., Ormerod, S., Panagopoulos, Y., Schmutz, S., Venohr, M., and Birk, S. 2015. Managing aquatic ecosystems and water resources under multiple stress - An introduction to the MARS project. Sci. Total Environ. 503-504: 10-21. doi:10.1016/j.scitotenv.2014.06.106.

Hickey, V. 2010. The Quagga Mussel Crisis at Lake Mead National Recreation Area, Nevada ( U . S . A .). Conserv. Biol. 24(4): 931-937. doi:DOI:10.1111/j.1523-1739.2010.01490.x.

Hölker, F., Wolter, C., Perkin, E.K., and Tockner, K. 2010. Light pollution as a biodiversity threat. Trends Ecol. Evol. 25(12): 681-682. doi:10.1016/j.tree.2010.09.007.

Howarth, C. 2014. Where to go ? Using Social Media to Assess the Spatial Distribution of Recreation on the Great Barrier Reef. Imperial College London.

Howat, G., and Assaker, G. 2013. The hierarchical effects of perceived quality on perceived 
value, satisfaction, and loyalty: Empirical results from public, outdoor aquatic centres in Australia. Sport Manag. Rev. 16(3): 268-284. Sport Management Association of Australia and New Zealand. doi:10.1016/j.smr.2012.10.001.

Hunt, L.M. 2005. Recreational Fishing Site Choice Models: Insights and Future Opportunities. Hum. Dimens. Wildl. 10(3): 153-172.

Hunt, L.M., Arlinghaus, R., Lester, N., and Kushneriuk, R. 2011. The effects of regional angling effort, angler behavior, and harvesting efficiency on landscape patterns of overfishing. Ecol. Appl. 21(7): 2555-2575. doi:10.1890/10-1237.1.

Hunt, L.M., Bannister, A.E., Drake, D.A.R., Fera, S.A., and Johnson, T.B. 2017. Do Fish Drive Recreational Fishing License Sales? North Am. J. Fish. Manag. 37(1): 122-132. Taylor \& Francis. doi:10.1080/02755947.2016.1245224.

Hunt, L.M., Boots, B.N., and Boxall, P.C. 2007. Predicting Fishing Participation and Site Choice While Accounting for Spatial Substitution, Trip Timing, and Trip Context. North Am. J. Fish. Manag. 27(3): 832-847. doi:10.1577/M06-079.1.

Hunt, L.M., Fenichel, E.P., Fulton, D.C., Mendelsohn, R., Smith, J.W., Tunney, T.D., Lynch, A.J., Paukert, C.P., and Whitney, J.E. 2016. Identifying Alternate Pathways for Climate Change to Impact Inland Recreational Fishers. Fisheries 41(7): 362-372. doi:10.1080/03632415.2016.1187015.

Ikomi, R.B., and Arimoro, F.O. 2014. Effects of recreational activities on the littoral macroinvertebrates of Ethiope River, Nider Delta, Nigeria. Assoc. Aquat. Sci. Niger. 29(1B): $155-170$.

Jacobsen, L., Baktoft, H., Jepsen, N., Aarestrup, K., Berg, S., and Skov, C. 2014. Effect of boat https://mc06.manuscriptcentral.com/er-pubs 
noise and angling on lake fish behaviour. J. Fish Biol. 84(6): 1768-1780. doi:10.1111/jfb.12395.

Jain-Schlaepfer, S.M.R., Blouin-demers, G., Cooke, S.J., and Bulté, G. 2017. Do boating and basking mix ? The effect of basking disturbances by motorboats on the body temperature and energy budget of the northern map turtle. Aquat. Conserv. Mar. Freshw. Ecosyst. 27: 547-558. doi:10.1002/aqc.2693.

Jobstvogt, N., Watson, V., and Kenter, J.O. 2014. Looking below the surface: The cultural ecosystem service values of UK marine protected areas (MPAs). Ecosyst. Serv. 10: 97-110. Elsevier. doi:10.1016/j.ecoser.2014.09.006.

Johnson, L.E., Ricciardi, A., and Carlton, J.T. 2001. Overland dispersal of aquatic invasive species: A risk assessment of transient recreational boating. Ecol. Appl. 11(6): 1789-1799. doi:10.1890/1051-0761(2001)011[1789:ODOAIS]2.0.CO;2.

Johnston, F.D., Arlinghaus, R., and Dieckmann, U. 2010. Erratum: Diversity and complexity of angler behaviour drive socially optimal input and output regulations in a bioeconomic recreational-fisheries model. Can. J. Fish. Aquat. Sci. 67(11): 1897-1898. doi:10.1139/F10113.

Johnston, F.D., Beardmore, B., and Arlinghaus, R. 2015. Optimal management of recreational fisheries in the presence of hooking mortality and noncompliance - predictions from a bioeconomic model incorporating a mechanistic model of angler behavior. Can. J. Fish. Aquat. Sci. 72: 37-53.

Johnstone, C., and Markandya, A. 2006. Valuing river characteristics using combined site choice and participation travel cost models. J. Environ. Manage. 80: 237-247. 
doi:10.1016/j.jenvman.2005.08.027.

Jones, D.N., and Reynolds, S.J. 2008. Feeding birds in our towns and cities : a global research opportunity. J. Avian Biol. 39: 265-271. doi:10.1111/j.2008.0908-8857.04271.x.

Jovanovic, B. 2015. Review of titanium dioxide nanoparticle phototoxicity: Developing a phototoxicity ratio to correct the endpoint values of toxicity tests. Environ. Toxicol. Chem. 34(5): 1070-1077. doi:10.1002/etc.2891.

Karwan, D.L., Aalto, R., Aufdenkampe, A.K., Denis Newbold, J., and Pizzuto, J.E. 2011. Characterization and source determination of stream suspended particulate material in White Clay Creek, USA. Appl. Geochemistry 26(SUPPL.): S354-S356. Elsevier Ltd. doi:10.1016/j.apgeochem.2011.03.058.

Keeler, B., Wood, S., Polasky, S., and Kling, C. 2015a. Recreational demand for clean water: evidence from geotagged photographs by visitors to lakes. Front. Ecol. Environ. 2(13): 7681. Available from http://www.esajournals.org/doi/10.1890/140124 [accessed 7 May 2015].

Keeler, B.L., Polasky, S., Brauman, K.A., Johnson, K.A., Finlay, J.C., O’Neill, A., Kovacs, K., and Dalzell, B. 2012. Linking water quality and well-being for improved assessment and valuation of ecosystem services. Proc. Natl. Acad. Sci. U. S. A. 109(45): 18619-24. doi:10.1073/pnas.1215991109.

Keeler, B.L., Wood, S.A., Polasky, S., Kling, C., Filstrup, C.T., and Downing, J.A. 2015 b. Recreational demand for clean water: Evidence from geotagged photographs by visitors to lakes. Front. Ecol. Environ. 13(2): 76-81. doi:10.1890/140124.

Kidd, K.R., Aust, W.M., and Copenheaver, C.A. 2014. Recreational stream crossing effects on sediment delivery and macroinvertebrates in southwestern Virginia, USA. Environ. Manage. 

54(3): 505-516. doi:10.1007/s00267-014-0328-5.

Kolstoe, S., and Cameron, T.A. 2017. The Non-market Value of Birding Sites and the Marginal Value of Additional Species : Biodiversity in a Random Utility Model of Site Choice by eBird Members. Ecol. Econ. 137: 1-12. Elsevier B.V. doi:10.1016/j.ecolecon.2017.02.013.

Konstantinou, I.K., and Albanis, T.A. 2004. Worldwide occurrence and effects of antifouling paint booster biocides in the aquatic environment: A review. Environ. Int. 30(2): 235-248. doi:10.1016/S0160-4120(03)00176-4.

Kummu, M., de Moel, H., Ward, P.J., and Varis, O. 2011. How close do we live to water? A global analysis of population distance to freshwater bodies. PLoS One 6(6): e20578. doi:10.1371/journal.pone.0020578.

Lee, L.-H., and Lee, Y.-D. 2015a. The impact of water quality on the visual and olfactory satisfaction of tourists. Ocean Coast. Manag. 105: 92-99. Elsevier Ltd. doi:10.1016/j.ocecoaman.2014.12.020.

Lee, W., and Lee, C.C. 2015b. Developmental toxicity of cigarette butts - An underdeveloped issue. Ecotoxicol. Environ. Saf. 113(2014): 362-368. Elsevier. doi:10.1016/j.ecoenv.2014.12.018.

Lester, L.A., Avery, H.W., Harrison, A.S., and Standora, E.A. 2013. Recreational boats and turtles: Behavioral mismatches result in high rates of injury. PLoS One 8(12): 1-8. doi:10.1371/journal.pone.0082370.

Lethlean, H., Dongen, W.F.D. Van, Kostoglou, K., Guay, P., and Weston, M.A. 2017. Landscape and Urban Planning Joggers cause greater avian disturbance than walkers. Landsc. Urban Plan. 159: 42-47. Elsevier B.V. doi:10.1016/j.landurbplan.2016.08.020. 
1 Leung, Y.-F., and Marion, J.L. 2000. Recreation impacts and management in wilderness: A state-

2 of-knowledge review. Wilderness Sci. a Time Chang. Wilderness Ecosyst. Threat. Manag.: 23-48. doi:10.1098/rspb.2005.3251.

Levin, S., Xepapadeas, T., Crépin, A.-S., Norberg, J., de Zeeuw, A., Folke, C., Hughes, T., Arrow, K., Barrett, S., Daily, G., Ehrlich, P., Kautsky, N., Mäler, K.-G., Polasky, S., Troell, M., Vincent, J.R., and Walker, B. 2013. Social-ecological systems as complex adaptive systems: modeling and policy implications. Environ. Dev. Econ. 18(2): 111-132. doi:https://doi.org/10.1017/S1355770X12000460.

Lewin, W.-C., Arlinghaus, R., and Mehner, T. 2006. Documented and Potential Biological Impacts of Recreational Fishing: Insights for Management and Conservation. Rev. Fish. Sci. 14(4): 305-367. doi:dx.doi.org/10.1080/10641260600886455.

Liddle, M.J. 1991. Recreation ecology: Effects of trampling on plants and corals. Trends Ecol. Evol. 6(1): 13-17. doi:10.1016/0169-5347(91)90141-J.

Liddle, M.J., and Scorgie, H.R.A. 1980. The effects of recreation on freshwater plants and animals: A review. Biol. Conserv. 17(3): 183-206. doi:10.1016/0006-3207(80)90055-5.

Liedermann, M., Tritthart, M., Gmeiner, P., Hinterleitner, M., Schludermann, E., Keckeis, H., and Habersack, H. 2014. Typification of vessel-induced waves and their interaction with different bank types, including management implications for river restoration projects. Hydrobiologia: 1-15. doi:10.1007/s10750-014-1829-1.

Loh, J., Green, R.E., Ricketts, T., Lamoreux, J., Jenkins, M., Kapos, V., and Randers, J. 2005. The Living Planet Index: using species population time series to track trends in biodiversity. Philos. Trans. R. Soc. Lond. B. Biol. Sci. 360(1454): 289-295. doi:10.1098/rstb.2004.1584. 
1 Loomis, J., and McTernan, J. 2014. Economic Value of Instream Flow for Non-Commercial

2 Whitewater Boating Using Recreation Demand and Contingent Valuation Methods.

3 Environ. Manage. 53: 1-10. doi:10.1007/s00267-014-0232-z.

4 Lorenz, S., Gabel, F., Dobra, N., and Pusch, M.T. 2013. Modelling the effects of recreational

5 boating on self-purification activity provided by bivalve mollusks in a lowland river.

$6 \quad$ Freshw. Sci. 32(1): 82-93. doi:10.1899/12-054.1.

7 Lorenz, S., and Pusch, M.T. 2012. Estimating the recreational carrying capacity of a lowland river section. Water Sci. Technol. 66(9): 2033-2039. doi:10.2166/wst.2012.418.

9 Luttik, J. 2000. The value of trees, water and open space as reflected by house prices in the Netherlands. Landsc. Urban Plan. 48(3-4): 161-167. doi:10.1016/S0169-2046(00)00039-6.

11 Maes, J., Teller, A., Erhard, M., Liquete, C., Braat, L., Berry, P., Egoh, B., Puydarrieux, P., Fiorina, C., Santos-Martín, F., and Maria Luisa Paracchini1, Hans Keune8, 19, Heidi Wittmer9, Jennifer Hauck9, Ingeborg Fiala10, Peter H. Verburg11, Sophie Condé12, Jan Philipp Schägner1, Jesús San Miguel1, Christine Estreguil1, Ole Ostermann1, José I.

Manfredo, M.J., Driver, B.L., and Tarrant, M. a. 1996. Measuring leisure motivation : A metaanalysis of the recreation experience preference scales. J. Leis. Res. 28(3): 188-213.

Manfrin, A., Singer, G., Larsen, S., Weiß, N., van Grunsven, R.H.A., Weiß, N.-S., Wohlfahrt, S., Monaghan, M.T., and Hölker, F. 2017. Artificial Light at Night Affects Organism Flux across Ecosystem Boundaries and Drives Community Structure in the Recipient Ecosystem. 
Front. Environ. Sci. 5(61). doi:10.3389/fenvs.2017.00061.

Manning, R.E. 2010. Studies in Outdoor Recreation: Search and Research for Satisfaction, Third Edition. Oregon State University Press, Corvallis. Available from http://osupress.oregonstate.edu/book/studies-in-outdoor-recreation-0.

Marion, J.L., Leung, Y.-F., Eagleston, H., and Burroughs, K. 2016. A Review and Synthesis of Recreation Ecology Research Findings on visitors Impacts to Wilderness and Protected Natural Areas. J. For. 3(114): 352-362. doi:http://dx.doi.org/10.5849/jof.15-498.

Martinez-Abrain, A., Oro, D., Jimenez, J., Stewart, G., and Pullin, A. 2010. A systematic review of the effects of recreational activities on nesting birds of prey. Basic Appl. Ecol. 11(4): 312-319. doi:10.1016/j.baae.2009.12.011.

Massey, D.M., Newbold, S.C., and Gentner, B. 2006. Valuing water quality changes using a bioeconomic model of a coastal recreational fishery. J. Environ. Econ. Manage. 52(1): 482500. doi:10.1016/j.jeem.2006.02.001.

Mccarthy, K.P., and Destefano, S. 2011. Effects of Spatial Disturbance on Common Loon Nest Site Selection and Territory Success. 75(2): 289-296. doi:10.1002/jwmg.50.

Mee, J.A., Post, J.R., Ward, H., Wilson, K.L., Newton, E., and Cantin, A. 2016. Interaction of ecological and angler processes: Experimental stocking in an open access, spatially structured fishery. Ecol. Appl. 26(6): 1693-1707. doi:10.1890/15-0879.1.

Melstrom, R.T., Lupi, F., Esselman, P.C., and Stevenson, R.J. 2015. Valuing recreational fishing quality at rivers and streams. Water Resour. Res. 51(1): 140-150. doi:10.1002/2014WR016152. 
1 Mitchell, L., Frank, M.R., Harris, K.D., Dodds, P.S., and Danforth, C.M. 2013. The Geography of Happiness: Connecting Twitter Sentiment and Expression, Demographics, and Objective Characteristics of Place. PLoS One 8(5): e64417. doi:10.1371/journal.pone.0064417.

Monz, C., Pickering, C.M., and Hadwen, W.L. 2013. Recent advances in recreation ecology and the implications of different relationships between recreation use and ecological impacts. Front. Ecol. Environ. 11(8): 441-446. doi:10.1890/120358.

Mosisch, T.D., and Arthington, A.H. 2001. Polycyclic aromatic hydrocarbon residues in the sediments of a dune lake as a result of power boating. Lakes Reserv. Res. Manag. 6: 21-32.

Munari, C., Corbau, C., Simeoni, U., and Mistri, M. 2015. Marine litter on Mediterranean shores: Analysis of composition, spatial distribution and sources in north-western Adriatic beaches. Waste Manag. 49: 483-490. Elsevier Ltd. doi:10.1016/j.wasman.2015.12.010.

Murphy, K.J., and Eaton, J.W. 1983. Effects of Pleasure-Boat Traffic on Macrophyte Growth in Canals. J. Appl. Ecol. 20(3): 713-729. Available from http://www.jstor.org/stable/2403122.

Naidoo, R., and Adamowicz, W. 2005. Biodiversity and nature-based tourism at forest reserves in Uganda. Environ. Dev. Econ. 10(2): 159-178. doi:doi:10.1017/S1355770X0400186X.

Navarro Jurado, E., Tejada Tejada, M., Almeida García, F., Cabello González, J., Cortés Macías, R., Delgado Pena, J., Fernández Gutiárrez, F., Gutiárrez Fernández, G., Luque Gallego, M., Malvarez Garcia, G., Marcenaro Gutierrez, O., Navas Concha, F., Ruiz de la Rua, F., Ruiz Sinoga, J., and Solis Becerra, F. 2012. Carrying capacity assessment for tourist destinations. Methodology for the creation of synthetic indicators applied in a coastal area. Tour. Manag. 33(6): 1337-1346. Elsevier Ltd. doi:10.1016/j.tourman.2011.12.017.

Niesar, M., Arlinghaus, R., Rennert, B., and Mehner, T. 2004. Coupling insights from a carp, 
Cyprinus carpio, angler survey with feeding experiments to evaluate composition, quality and phosphorus input of groundbait in coarse fishing. Fish. Manag. Ecol. 11(3-4): 225-235. doi:10.1111/j.1365-2400.2004.00400.x.

4 Nyström, B., Becker-Van Slooten, K., Bérard, A., Grandjean, D., Druart, J.C., and Leboulanger, Water Res. 36(8): 2020-2028. doi:10.1016/S0043-1354(01)00404-3.

O’Toole, A.C., Hanson, K.C., and Cooke, S.J. 2009. The Effect of Shoreline Recreational Angling Activities on Aquatic and Riparian Habitat Within an Urban Environment : Implications for Conservation and Management. Environ. Manage. 44: 324-334. doi:DOI 10.1007/s00267-009-9299-3.

Orams, M.B. 2002. Feeding wildlife as a tourism attraction : a review of issues and impacts. Tour. Manag. 23: 281-293.

Orsi, F., and Geneletti, D. 2013. Using geotagged photographs and GIS analysis to estimate visitor flows in natural areas. J. Nat. Conserv. 21(5): 359-368. Elsevier GmbH. doi:10.1016/j.jnc.2013.03.001.

Ostendorp, W., Schmieder, K., and Jöhnk, K. 2004. Assessment of human pressures and their hydromorphological impacts on lakeshores in Europe. Int. J. Ecohydrol. 4(4): 379-395.

Parsons, G.R., and Jo Kealy, M. 1994. Benefits transfer in a random utility model of recreation. Water Resour. Res. 30(8): 2477-2484. doi:10.1029/94WR01047.

Pease, M.L., Rose, R.K., and Butler, M.J. 2005. Effects of human disturbance on the behavior wintering ducks. Wildl. Soc. Bull. 33(1): 103-112. doi:https://doi.org/10.2193/00917648(2005)33[103:EOHDOT]2.0.CO;2. 
1 Pendleton, L.H. 1994. Environmental quality and recreation demand in a caribbean coral reef. Coast. Manag. 22(4): 399-404. doi:10.1080/08920759409362246.

Perkin, E.K., Hölker, F., Richardson, J.S., Sadler, J.P., Wolter, C., and Tockner, K. 2011. The influence of artificial light on stream and riparian ecosystems: questions, challenges, and perspectives. Ecosphere 2(11): art122. doi:10.1890/ES11-00241.1.

Pickering, C.M., and Hill, W. 2007. Impacts of recreation and tourism on plant biodiversity and vegetation in protected areas in Australia. J. Environ. Manage. 85(4): 791-800. doi:10.1016/j.jenvman.2006.11.021.

Piryani, R., Madhavi, D., and Singh, V.K. 2017. Analytical mapping of opinion mining and sentiment analysis research during 2000-2015. Inf. Process. Manag. 53(1): 122-150. Elsevier Ltd. doi:10.1016/j.ipm.2016.07.001.

Post, J.R., Persson, L., Parkinson, E.A., and Kooten, T. van. 2008. Angler numerical response across landscapes and the collapse of freshwater fisheries. Ecol. Appl. 18: 1038-1049. doi:http://dx.doi.org/10.1890/07-0465.1.

Preißler, S. 2008. Wasserqualität an europäischen Küsten und ihre Bewertung durch Touristen. Edited byG. Schernewski and N. Stybel. EUCC - Die Küsten Union Deutschland e.V., Hamburg. Available from http://databases.eucc-d.de/files/documents/00000738_IKZMOder_Berichte54.pdf.

Pretty, J., Peacock, J., Hine, R., Sellens, M., South, N., and Griffin, M. 2007. Green exercise in the UK countryside: Effects on health and psychological well-being, and implications for policy and planning. J. Environ. Plan. Manag. 50(2): 211-231. doi:10.1080/09640560601156466. 
1 Rankin, B.L., Ballantyne, M., and Pickering, C.M. 2015. Tourism and recreation listed as a threat 2 for a wide diversity of vascular plants: A continental scale review. J. Environ. Manage. 154: 293-298. Elsevier Ltd. doi:10.1016/j.jenvman.2014.10.035.

4 Raudsepp-Hearne, C., Peterson, G.D., Tengö, M., Bennett, E.M., Holland, T., Benessaiah, K., 5 MacDonald, G.K., and Pfeifer, L. 2010. Untangling the Environmentalist's Paradox: Why Is

Roche, R.C., Monnington, J.M., Newstead, R.G., Sambrook, K., Griffith, K., Holt, R.H.F., and Jenkins, S.R. 2015. Recreational vessels as a vector for marine non-natives: developing biosecurity measures and managing risk through an in-water encapsulation system. Hydrobiologia 750(1): 187-199. doi:10.1007/s10750-014-2131-y.

Roder Green, A.L., Putschew, A., and Nehls, T. 2014. Littered cigarette butts as a source of nicotine in urban waters. J. Hydrol. 519(PD): 3466-3474. Elsevier B.V. doi:10.1016/j.jhydrol.2014.05.046.

Russi, D., ten Brink, P., Farmer, A., Badura, T., Coates, D., Förster, J., Kumar, R., Davidson, N., and Russi, Daniela; ten Brink, Patrick; Farmer, Andrew; Badura, Tomas; Coates, David; Förster, Johannes; Kumar, Ritesh; Davidson, N. 2012. The Economics of Ecosystems and Biodiversity for Water and Wetlands (TEEB),. doi:10.1007/s13398-014-0173-7.2.

Salerno, F., Viviano, G., Manfredi, E.C., Caroli, P., Thakuri, S., and Tartari, G. 2013. Multiple Carrying Capacities from a management-oriented perspective to operationalize sustainable 
tourism in protected areas. J. Environ. Manage. 128: 116-125. Elsevier Ltd. doi:10.1016/j.jenvman.2013.04.043.

Santiago, L.E., Gonzalez-Caban, A., and Loomis, J. 2008. A model for predicting daily peak visitation and implications for recreation management and water quality: Evidence from two rivers in Puerto Rico. Environ. Manage. 41(6): 904-914. doi:10.1007/s00267-008-9079-5.

Santos-Martín, F., Martín-López, B., García-Llorente, M., Aguado, M., Benayas, J., and Montes, C. 2013. Unraveling the relationships between ecosystems and human wellbeing in Spain. PLoS One 8(9): e73249. doi:10.1371/journal.pone.0073249.

Schludermann, E., Liedermann, M., Hoyer, H., Tritthart, M., Habersack, H., and Keckeis, H. 2014. Effects of vessel-induced waves on the YOY-fish assemblage at two different habitat types in the main stem of a large river (Danube, Austria). Hydrobiologia 729(1): 3-15. doi:10.1007/s10750-013-1680-9.

Schlüter, M., McAllister, R.R.J., Arlinghaus, R., Bunnefeld, N., Eisenack, K., Hölker, F., MilnerGulland, E.J., Müller, B., Nicholson, E., Quaas, M., and Stöven, M. 2012. New horizons for managing the environment: A review of coupled social-ecological systems modeling. Nat. Recource Model. 25(1): 219-272.

Schmitt, C., Oetken, M., Dittberner, O., and Wagner, M. 2008. Endocrine modulation and toxic effects of two commonly used UV screens on the aquatic invertebrates Potamopyrgus antipodarum and Lumbriculus variegatus. Environ. Pollut. 152: 322-329. doi:10.1016/j.envpol.2007.06.031.

Schummer, M.L.., and Eddleman, W.R.. 2003. Effects of Disturbance on Activity and Energy Budgets of Migrating Waterbirds in South-Central Oklahoma. J. Wildl. Manage. 67(4): 789- 
795.

Selman, W., Sciences, B., and Drive, C. 2013. Effects of Human Disturbance on the Behavior and Physiology of an Imperiled Freshwater Turtle. J. Wildl. Manag. 77(5): 877-885. doi:10.1002/jwmg.538.

Shelby, B., and Heberlein, T.A. 1986. Carrying capacity in recreation settings. Oregon State University Press, Corvallis. Available from http://osupress.oregonstate.edu/book/carryingcapacity-in-recreation-settings.

Shepherd, E., Milner-Gulland, E.J., Knight, A.T., Ling, M.A., Darrah, S., van Soesbergen, A., and Burgess, N.D. 2016. Status and Trends in Global Ecosystem Services and Natural Capital: Assessing Progress Toward Aichi Biodiversity Target 14. Conserv. Lett. 9(6): 429437. doi:10.1111/conl.12320.

Siikamäki, P., Kangas, K., Paasivaara, A., and Schroderus, S. 2015. Biodiversity attracts visitors to national parks. Biodivers. Conserv. 24(10): 2521-2534. doi:10.1007/s10531-015-0941-5.

Silva, C.G. 2014. Calculating Willingness-To-Pay As a Function of Biophysical Water Quality and Water Quality Perceptions by. Utah State University. Available from http://digitalcommons.usu.edu/etd/3325.

Simpson, S.D., Radford, A.N., Nedelec, S.L., Ferrari, M.C.O., Chivers, D.P., McCormick, M.I., and Meekan, M.G. 2016. Anthropogenic noise increases fish mortality by predation. Nat. Commun. 7: 10544. Nature Publishing Group. doi:10.1038/ncomms10544.

Smith, A.J., Duffy, B.T., and Novak, M.A. 2015. Observer rating of recreational use in wadeable streams of New York State, USA: Implications for nutrient criteria development. Water Res. 69: 195-209. Elsevier Ltd. doi:10.1016/j.watres.2014.11.022. 
1 Sonter, L.J., Watson, K.B., Wood, S.A., and Ricketts, T.H. 2016. Spatial and temporal dynamics and value of nature-based recreation, estimated via social media. PLoS One 11(9): 1-16. doi:10.1371/journal.pone.0162372.

Sorice, M.G., Oh, C., and Ditton, R.B. 2017. Royal Swedish Academy of Sciences Managing Scuba Divers to Meet Ecological Goals for Coral Reef Conservation Linked references are available on JSTOR for this article : Managing Scuba Divers to Meet Ecological Goals for Coral Reef Conservation. 36(4): 316-322.

Steenhof, K., Brown, J.L., and Kochert, M.N. 2014. Temporal and spatial changes in golden eagle reproduction in relation to increased off highway vehicle activity. Wildl. Soc. Bull. 38(4): 682-688. doi:10.1002/wsb.451.

Steinwender, A., Gundacker, C., and Wittmann, K.J. 2008. Objective versus subjective assessments of environmental quality of standing and running waters in a large city. Landsc. Urban Plan. 84(2): 116-126. doi:10.1016/j.landurbplan.2007.07.001.

Steven, R., Pickering, C., and Guy Castley, J. 2011. A review of the impacts of nature based recreation on birds. J. Environ. Manage. 92(10): 2287-2294. Elsevier Ltd. doi:10.1016/j.jenvman.2011.05.005.

Stewart, A.M., Grossman, L., Collier, A.D., Echevarria, D.J., and Kalueff, A. V. 2015. Anxiogenic-like effects of chronic nicotine exposure in zebrafish. Pharmacol. Biochem. Behav. 139: 112-120. Elsevier Inc. doi:10.1016/j.pbb.2015.01.016.

Stoll-Kleemann, S. 2010. Reconciling Opposition to Protected Areas Management in Europe: The German Experience. Sci. Policy Sustain. Dev. 43(5): 32-44. doi:dx.doi.org/10.1080/00139150109605145. 
1 Sweeney, B.W., and Newbold, J.D. 2014. Streamside forest buffer width needed to protect stream

2 water quality, habitat, and organisms: A literature review. J. Am. Water Resour. Assoc. 50(3): 560-584. doi:10.1111/jawr.12203.

Taplin, R.H. 2013. The influence of competition on visitor satisfaction and loyalty. Tour. Manag. 36: 238-246. doi:10.1016/j.tourman.2012.12.012.

Terrado, M., Momblanch, A., Bardina, M., Boithias, L., Munné, A., Sabate, S., Solera, A., and Acuna, V. 2016. Integrating ecosystem services in river basin management plans. J. Appl. Ecol. 53: 865-875. doi:10.1111/1365-2664.12613.

Tjärnlund, U., Ericson, G., Lindesjöö, E., Petterson, I., Akerman, G., and Balk, L. 1996. Further Studies of the Effects of Exhaust from Two-Stroke Outboard Motors on Fish. Mar. Environ. Res. 42(1-4): 267-271.

Turner, A.M., and Ruhl, N. 2007. Phosphorus Loadings Associated with a Park Tourist Attraction : Limnological Consequences of Feeding the Fish. Environ. Manage. 39: 526533. doi:10.1007/s00267-005-0155-9.

Vesterinen, J., Pouta, E., Huhtala, A., and Neuvonen, M. 2010. Impacts of changes in water quality on recreation behavior and benefits in Finland. J. Environ. Manage. 91(4): 984-994. Elsevier Ltd. doi:10.1016/j.jenvman.2009.12.005.

Vidal-Abarca, M. 2014. Understanding complex links between fluvial ecosystems and social indicators in Spain: An ecosystem services approach. Ecol. Complex. 20: 1-10. doi:10.1016/j.ecocom.2014.07.002.

Villamagna, A.M., Mogollón, B., and Angermeier, P.L. 2014. A multi-indicator framework for mapping cultural ecosystem services : The case of freshwater recreational fishing. Ecol. 
Indic. 45: 255-265. Elsevier Ltd. doi:10.1016/j.ecolind.2014.04.001.

2

3

4

5

6

Viñals, M.J., Planelles, M., Alonso-Monasterio, P., and Morant, M. 2016. Recreational carrying capacity on small mediterranean islands. Cuad. Tur. 37(September 2015): 437-463. doi:http://dx.doi.org/10.6018/turismo.37.256341.

Vlasov, B.P. 2012. Recreational use and environmental problems of lakes of protected areas in Belarus. Acta Geogr. Silesiana (11): 1-74.

Völker, S., and Kistemann, T. 2011. The impact of blue space on human health and well-being Salutogenetic health effects of inland surface waters: A review. Int. J. Hyg. Environ. Health 214(6): 449-460. doi:10.1016/j.ijheh.2011.05.001.

Völker, S., and Kistemann, T. 2013. Reprint of: “I'm always entirely happy when I'm here!” Urban blue enhancing human health and well-being in Cologne and Düsseldorf, Germany. Soc. Sci. Med. 91: 141-152. Elsevier Ltd. doi:10.1016/j.socscimed.2013.04.016.

Ward, H.G., Askey, P.J., and Post, J.R. 2013a. A mechanistic understanding of hyperstability in catch per unit effort and density-dependent catchability in a multistock recreational fishery. Can. J. Fish. Aquat. Sci. 70(10): 1542-1550.

Ward, H.G., Quinn, M.S., and Post, J.R. 2013b. Angler Characteristics and Management Implications in a Large, Multistock, Spatially Structured Recreational Fishery. North Am. J. Fish. Manag. 33(3): 576-584.

Waterkeyn, A., Vanschoenwinkel, B., Elsen, S., and Anton-pardo, M. 2010. Unintentional dispersal of aquatic invertebrates via footwear and motor vehicles in a Mediterranean wetland area. Aquat. Conserv. Mar. Freshw. Ecosyst. 587: 580-587. doi:10.1002/aqc.1122. 
1 Weirich, C.A., and Miller, T.R. 2014. Freshwater harmful algal blooms: Toxins and children's 2 health. Curr. Probl. Pediatr. Adolesc. Health Care 44(1): 2-24. Elsevier. doi:10.1016/j.cppeds.2013.10.007.

4 Weisbrod, C.J., Kunz, P.Y., Zenker, A.K., and Fent, K. 2007. Effects of the UV filter

Weyland, F., and Laterra, P. 2014. Recreation potential assessment at large spatial scales: A method based in the ecosystem services approach and landscape metrics. Ecol. Indic. 39: 34-43. Elsevier Ltd. doi:10.1016/j.ecolind.2013.11.023.

Whitehead, J.C., Pattanayak, S.K., Van Houtven, G.L., and Gelso, B.R. 2008. Combining Revealed and Stated Preference Data to Estimate the Nonmarket Value of Ecological Services: An Assessment of the State of the Science. J. Econ. Surv. 22(5): 872-908. doi:DOI 10.1111/j.1467-6419.2008.00552.x.

Whitfield, A.K., and Becker, A. 2014. Impacts of recreational motorboats on fishes: A review. Mar. Pollut. Bull. 83(1): 24-31. Elsevier Ltd. doi:10.1016/j.marpolbul.2014.03.055.

Wolff, S., Schulp, C.J.E., and Verburg, P.H. 2015. Mapping ecosystem services demand: A review of current research and future perspectives. Ecol. Indic. 55: 159-171. Elsevier Ltd. doi:10.1016/j.ecolind.2015.03.016.

Wolter, C., and Arlinghaus, R. 2003. Navigation impacts on freshwater fish assemblages: The 


\section{9}

ecological relevance of swimming performance. Rev. Fish Biol. Fish. 13(1): 63-89. doi:10.1023/A:1026350223459.

Wolter, C., Arlinghaus, R., Grosch, U., and Vilcinskas, A. 2003. Fische \& Fischerei in Berlin. Zeitschrift für Fischkd. Supplement: 163.

Wood, S., Guerry, A., Silver, J., and Lacayo, M. 2013. Using social media to quantify naturebased tourism and recreation. Sci. Rep. 3: 2976. doi:10.1038/srep02976.

Wyles, K.J., Pahl, S., and Thompson, R.C. 2014. Perceived risks and benefits of recreational visits to the marine environment: Integrating impacts on the environment and impacts on the visitor. Ocean Coast. Manag. 88: 53-63. The Authors. doi:10.1016/j.ocecoaman.2013.10.005.

Wynen, J. 2013. Explaining travel distance during same-day visits. Tour. Manag. 36: 133-140. Elsevier. doi:10.1016/j.tourman.2012.11.007.

Wysocki, T., and Gavin, L. 2006. Paternal involvement in the management of pediatric chronic diseases: Associations with adherence, quality of life, and health status. J. Pediatr. Psychol. 31(5): 501-511. doi:10.1016/j.biocon.2005.10.020.

Zhang, L., and Chung, S.S. 2015. Assessing the Social Carrying Capacity of Diving Sites in Mabul Island, Malaysia. Environ. Manage. 56(6): 1467-1477. Springer US. doi:10.1007/s00267-015-0586-X. 
1 Table 1. Examples of potential freshwater impacts on different organizational levels related to 2 recreational activities and respective pressures. Pressures are [1] presence / disturbance (e.g. 3 sudden or rapid movement) / feeding, [2] noise, [3] physical damage / damage of streambed

4 sediment structure (from trampling, vegetation clearance, litter, propellers, paddles), [4] turbidity

5 / creation of waves, [5] light pollution / reduced light penetration, [6] nutrient input (from urea,

6 skin, bait, feeding animals, sewage discharge), [7] chemical input (from spillage of engine oil,

7 exhausts, litter, sunscreens, cosmetics, insect repellents and biocides), [8] exploitation (e.g.

8 overfishing), [9] introduction of invasive species (from fish stocking/illegal release of fishes,

9 several vectors as ships, vehicles, soles), [10] pathogen input. 
1 Figure 1. Conceptual relationships among recreation quality, recreation demand and use, and

2 ecosystem impacts. Dashed lines in panel a) indicate varying effects of poor ecosystem quality on

3 different recreation types. Grey boxes indicate areas where social carrying capacity (a) and

4 ecological carrying capacity (b) are likely to exert effects or be exceeded.

5 Figure 2. Scenarios for relationships among improved ecosystem quality and recreational

6 demand and use leading to either amplifying or dampening feedbacks depending on whether

7 ecological or social carrying capacities are exceeded or not, with resulting effects on future

8 demand and use.

$9 \quad$ Figure 3. The multi-loop concept linking ecological quality, recreational quality, and ecosystem

10 management that is responsive to recreational quality.

11 Figure 4. Sum of daily visitors in dependence of the maximum daily air temperature in natural

12 bathing waters of Berlin during 2013 and 2015 (gray areas describe the $95 \%$ confidence interval;

13 data provided by $\mathrm{BBB})$. 


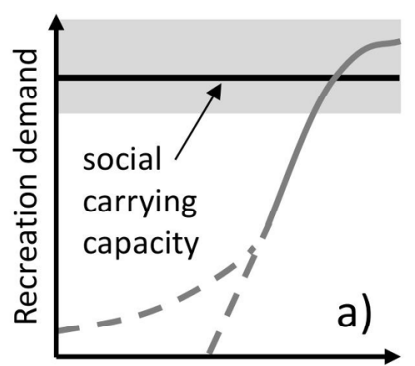

Ecosystem quality

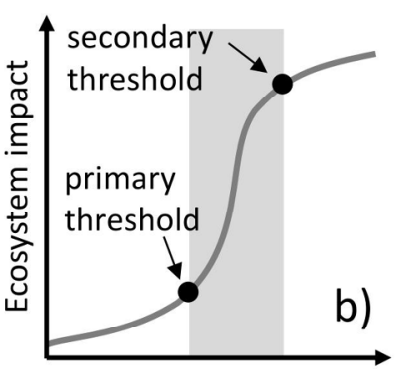

Recreation use

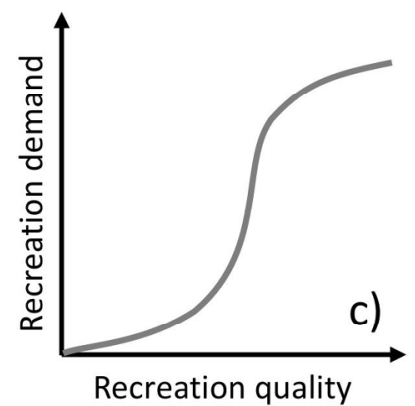

Recreation quality

Conceptual relationships among recreation quality, recreation demand and use, and ecosystem impacts. Dashed lines in panel a) indicate varying effects of poor ecosystem quality on different recreation types. Grey boxes indicate areas where social carrying capacity (a) and ecological carrying capacity (b) are likely to exert effects or be exceeded.

$170 \times 60 \mathrm{~mm}(300 \times 300 \mathrm{DPI})$ 


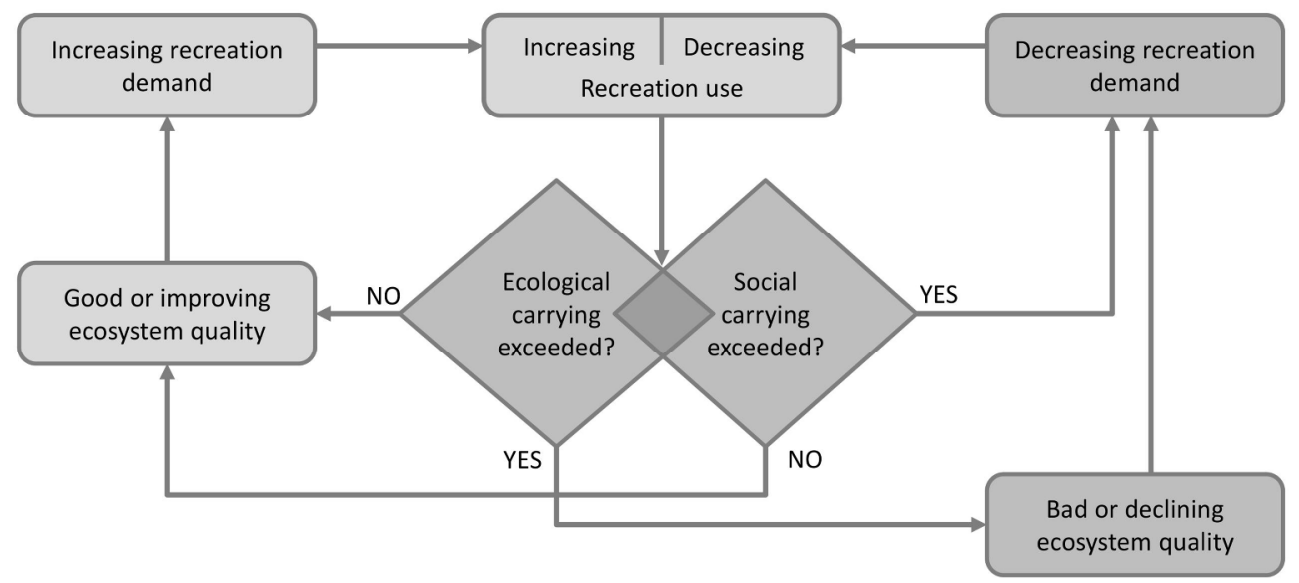

Scenarios for relationships among improved ecosystem quality and recreational demand and use leading to either amplifying or dampening feedbacks depending on whether ecological or social carrying capacities are exceeded or not, with resulting effects on future demand and use.

$220 \times 100 \mathrm{~mm}(300 \times 300 \mathrm{DPI})$ 


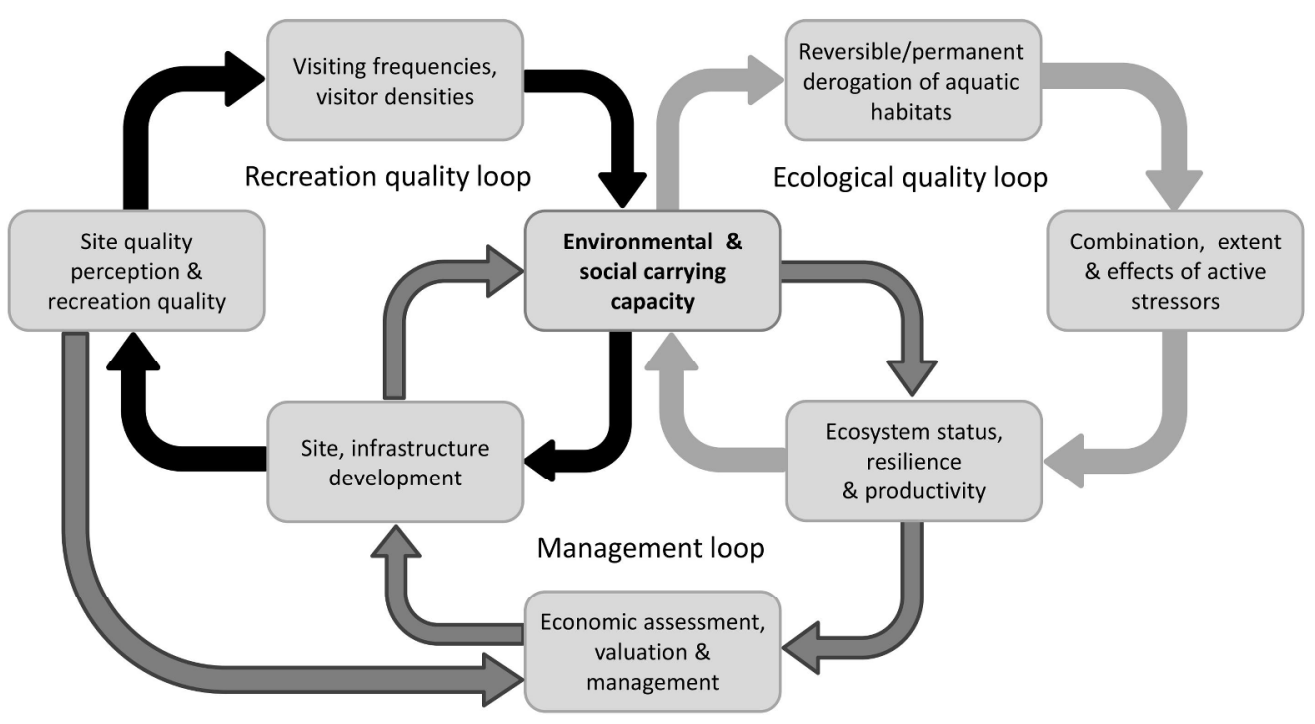

The multi-loop concept linking ecological quality, recreational quality, and ecosystem management that is responsive to recreational quality.

$240 \times 130 \mathrm{~mm}(300 \times 300 \mathrm{DPI})$ 


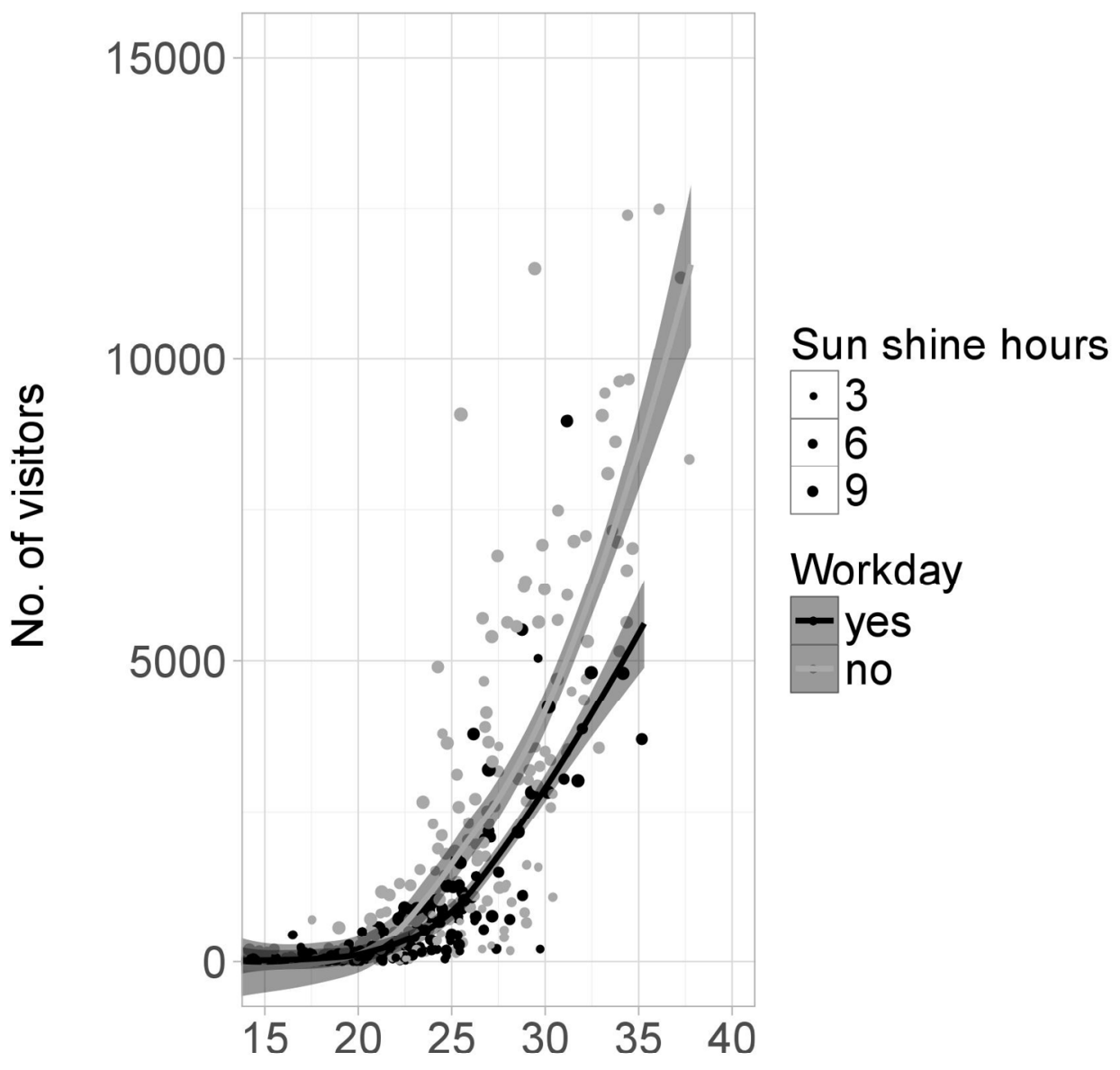

Maximum daily air temperature in Berlin, in ${ }^{\circ} \mathrm{C}$

Sum of daily visitors in dependence of the maximum daily air temperature in natural bathing waters of Berlin during 2013 and 2015 (gray areas describe the $95 \%$ confidence interval; data provided by BBB).

$149 \times 149 \mathrm{~mm}(300 \times 300 \mathrm{DPI})$ 
1 Table 1. Examples of potential freshwater impacts on different organizational levels related to recreational activities and respective pressures. Pressures are [1] presence / disturbance (e.g. sudden or rapid movement) / feeding, [2] noise, [3] physical damage / damage of streambed sediment structure (from trampling, vegetation clearance, litter, propellers, paddles), [4] turbidity / creation of waves, [5] light pollution / reduced light penetration, [6] nutrient input (from urea, skin, bait, feeding animals, sewage discharge), [7] chemical input (from spillage of engine oil, exhausts, litter, sunscreens, cosmetics, insect repellents and biocides), [8] exploitation (e.g. overfishing), [9] 6 introduction of invasive species (from fish stocking/illegal release of fishes, several vectors as ships, vehicles, soles), [10] pathogen input.

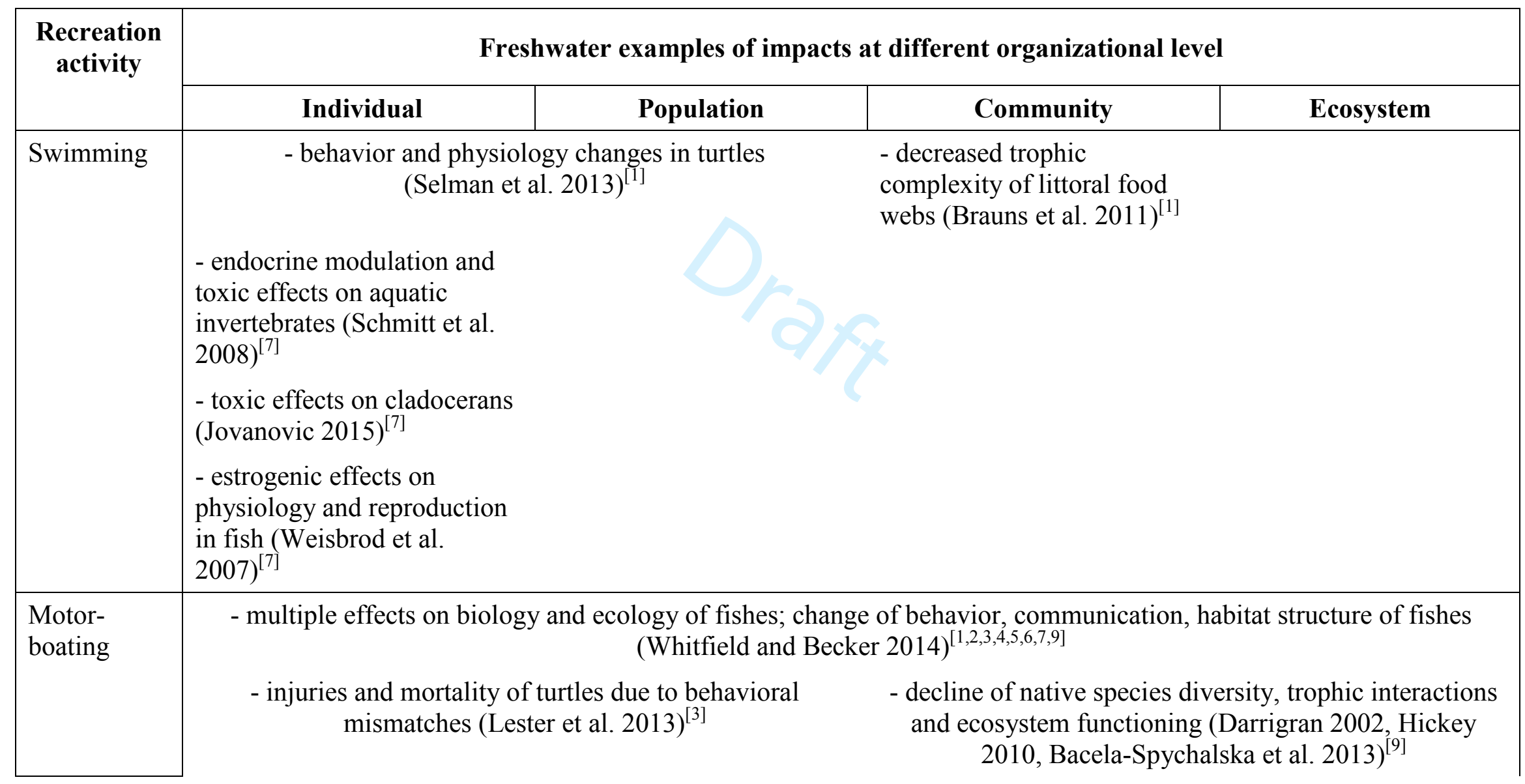




\begin{tabular}{|c|c|c|c|c|}
\hline \multirow{2}{*}{$\begin{array}{l}\text { Recreation } \\
\text { activity }\end{array}$} & \multicolumn{4}{|c|}{ Freshwater examples of impacts at different organizational level } \\
\hline & Individual & Population & Community & Ecosystem \\
\hline & \multicolumn{2}{|c|}{$\begin{array}{l}\text { - alteration of swimming speed and habitat use of fish } \\
\text { species (Jacobsen et al. 2014) }\end{array}$} & $\begin{array}{l}\text { - negative impacts on plants } \\
\text { (decrease of submerged and } \\
\text { floating plants) and animals } \\
\text { (Liddle and Scorgie } \\
1980)^{[1,2,3,4,6,7]}\end{array}$ & $\begin{array}{l}\text { - reduced self- } \\
\text { purification activity } \\
\text { through behavior } \\
\text { changes of bivalve } \\
\text { mollusks } \\
\text { (Lorenz et al. 2013) }^{[4]}\end{array}$ \\
\hline & $\begin{array}{l}\text { - increased cortisol secretion } \\
\text { in fish (Wysocki and Gavin } \\
2006)^{[2]}\end{array}$ & $\begin{array}{l}\text { - increased fish mortality by } \\
\text { predation (Simpson et al. } \\
2016)^{[2]}\end{array}$ & $\begin{array}{l}\text { - effect on invertebrates-fish } \\
\text { interaction and dislodges } \\
\text { benthic invertebrates (Gabel } \\
\text { et al. 2011, 2012) }\end{array}$ & $\begin{array}{l}\text { - effects on sediment and } \\
\text { nutrient budget, } \\
\text { planktonic, benthic and } \\
\text { fish communities } \\
(\text { Gabel et al. 2017) }\end{array}$ \\
\hline & $\begin{array}{l}\text { - sublethal physiological } \\
\text { disturbances of fish (Graham } \\
\text { and Cooke 2008) }\end{array}$ & $\begin{array}{l}\text { - changed nesting behavior } \\
\text { of birds (Boyle and Samson } \\
1985 \text {, Burger 1998) }\end{array}$ & $\begin{array}{l}\text { - decline of freshwater plant } \\
\text { species richness (Helmers et } \\
\text { al. 2016) }\end{array}$ & $\begin{array}{l}\text { - remobilizing } \\
\text { sediments, thus indirect } \\
\text { effects on } \\
\text { biogeochemical cycles } \\
\text { in aquatic ecosystems } \\
\text { (Beachler and Hill 2003, } \\
\text { Ikomi and Arimoro } \\
2014)^{[4]}\end{array}$ \\
\hline & $\begin{array}{l}\text { - toxic effects on aquatic } \\
\text { organisms (Mosisch and } \\
\text { Arthington } 2001 \text {, } \\
\text { Konstantinou and Albanis } \\
2004)^{[7]}\end{array}$ & $\begin{array}{l}\text { - increased alertness and } \\
\text { energy expenditure of birds } \\
\text { by boat fishing (Schummer } \\
\text { and Eddleman } 2003)^{[2]}\end{array}$ & $\begin{array}{l}\text { - change in community } \\
\text { composition and abundance } \\
\text { of aquatic macrophyte } \\
\text { (Murphy and Eaton } \\
1983)^{[3,4,5,7]}\end{array}$ & $\begin{array}{l}\text { - dispersal of aquatic } \\
\text { invasive species by } \\
\text { transient recreational } \\
\text { boating (Johnson et al. } \\
2001)^{[9]}\end{array}$ \\
\hline & $\begin{array}{l}\text { - disruption of biological } \\
\text { functions in rainbow trout } \\
\text { (Tjärnlund et al. 1996) }^{[7]}\end{array}$ & $\begin{array}{l}\text { - decreased rate of energy } \\
\text { assimilation of basking } \\
\text { animals }\end{array}$ & $\begin{array}{l}\text { - increased drift densities of } \\
\text { young-of-the-year fish } \\
\text { (Schludermann et al. 2014) }\end{array}$ & \\
\hline
\end{tabular}




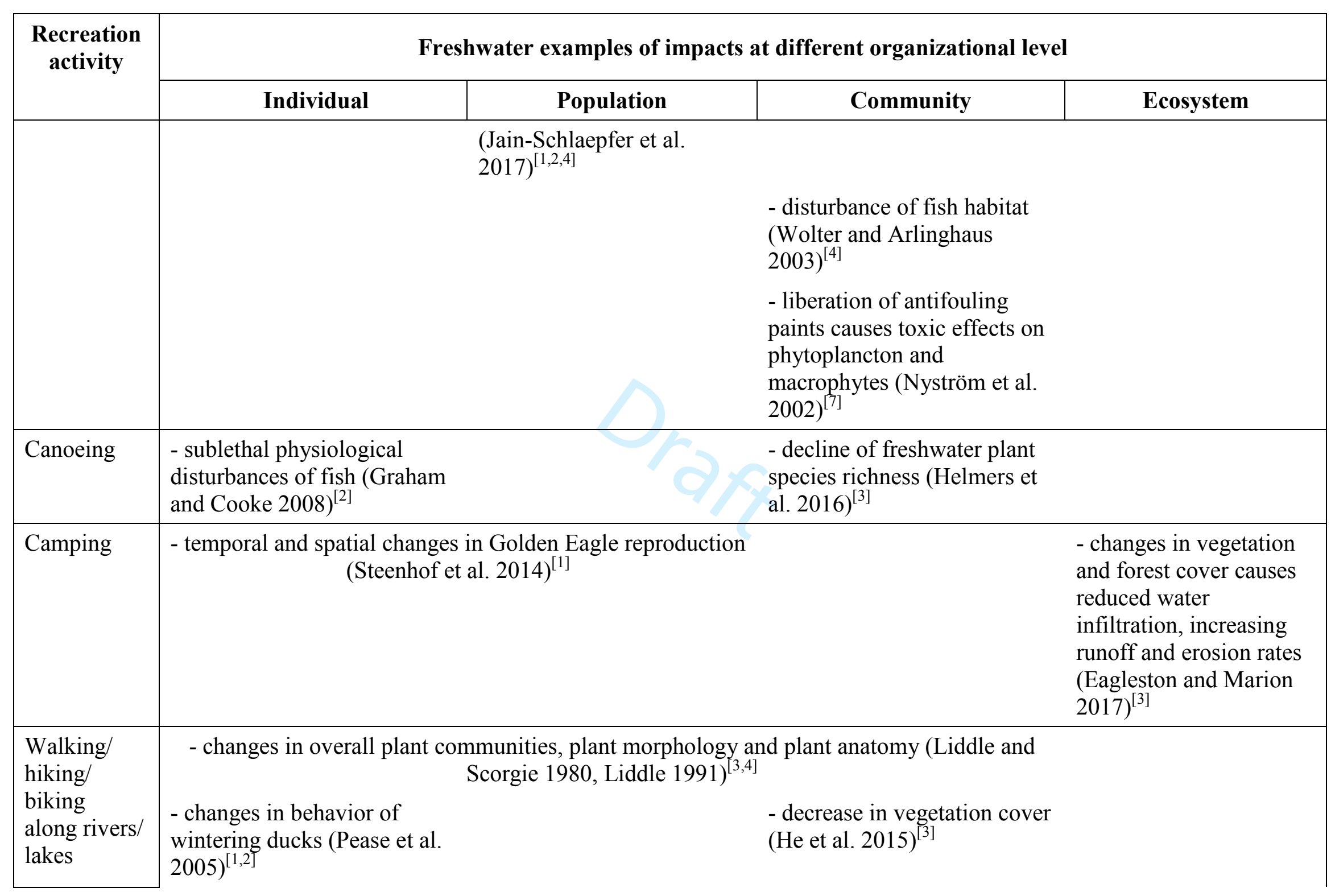




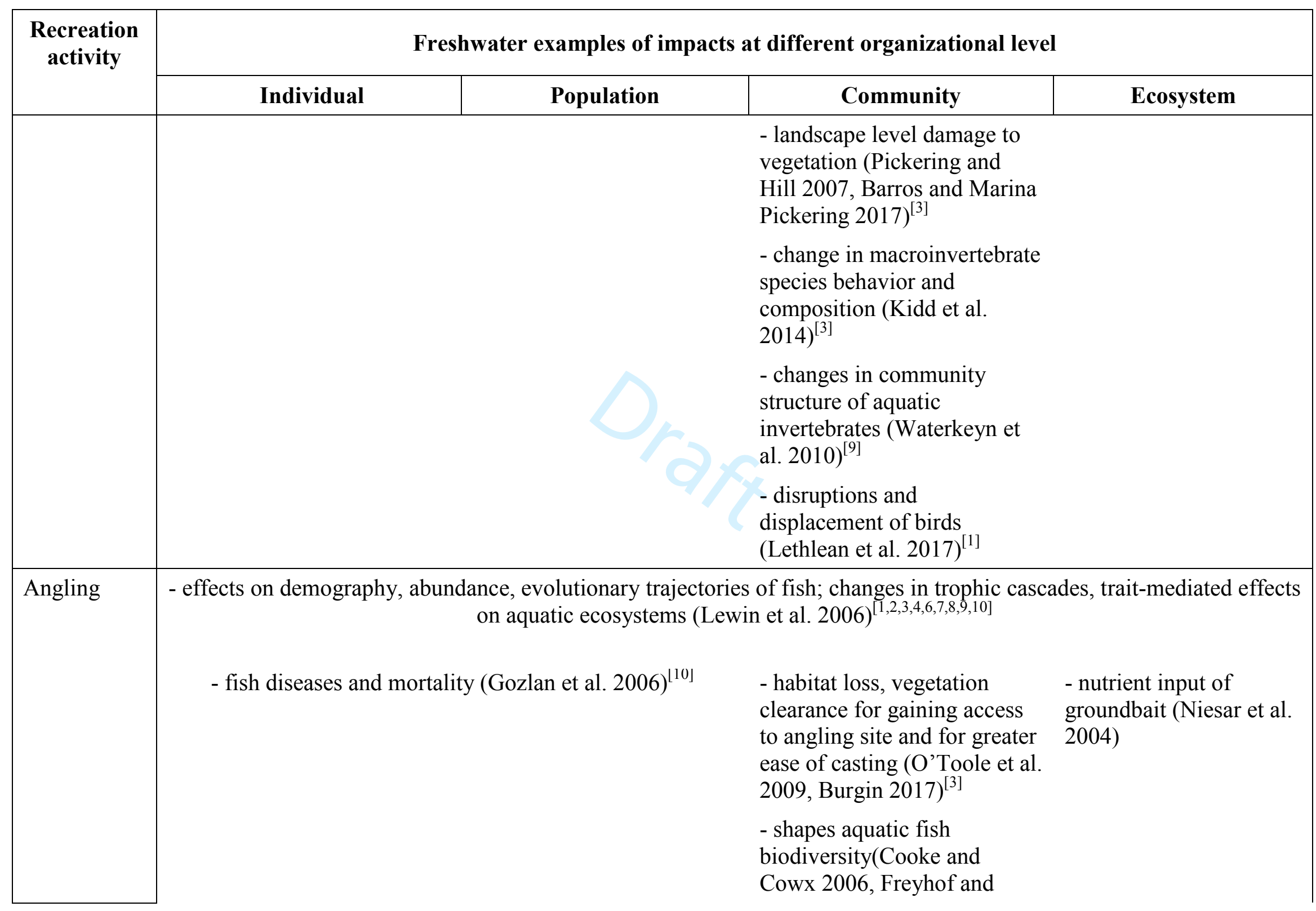




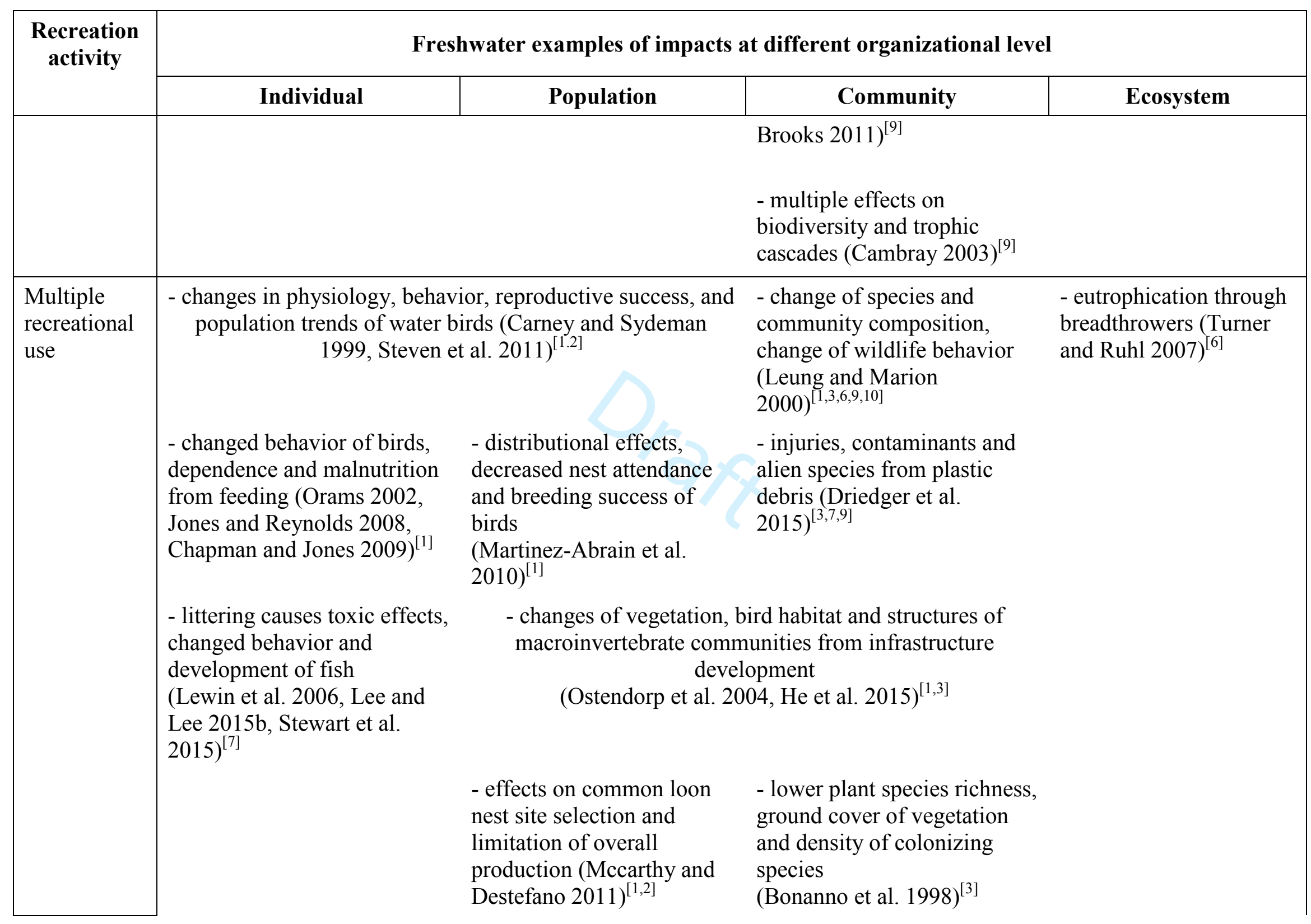




\begin{tabular}{|l|c|c|c|c|}
\hline \multirow{2}{*}{$\begin{array}{c}\text { Recreation } \\
\text { activity }\end{array}$} & \multicolumn{4}{|c|}{ Freshwater examples of impacts at different organizational level } \\
\cline { 2 - 4 } & Individual & \multicolumn{1}{|c|}{ Population } & \multicolumn{1}{c|}{ Community } & Ecosystem \\
\hline & & & $\begin{array}{l}\text { - alteration of organism flux } \\
\text { and community structure of } \\
\text { invertebrates (Manfrin et al. } \\
2017)^{[5]}\end{array}$ \\
& & $\begin{array}{l}\text { - decrease of periphyton } \\
\text { biomass (Grubisic et al. } \\
\text { 2017) }\end{array}$ \\
\end{tabular}

